\title{
Sick building syndrome: are we doing enough?
}

Article

Accepted Version

Ghaffarianhoseini, A., AlWaer, H., Omrany, H.,

Ghaffarianhoseini, A., Alalouch, C., Clements-Croome, D. and

Tookey, J. (2018) Sick building syndrome: are we doing enough? Architectural Science Review, 61 (3). pp. 99-121. ISSN 0003-8628 doi:

https://doi.org/10.1080/00038628.2018.1461060 Available at https://centaur.reading.ac.uk/76976/

It is advisable to refer to the publisher's version if you intend to cite from the work. See Guidance on citing.

To link to this article DOI: http://dx.doi.org/10.1080/00038628.2018.1461060

Publisher: Taylor \& Francis

All outputs in CentAUR are protected by Intellectual Property Rights law, including copyright law. Copyright and IPR is retained by the creators or other copyright holders. Terms and conditions for use of this material are defined in the End User Agreement.

\section{www.reading.ac.uk/centaur}

\section{CentAUR}


Central Archive at the University of Reading

Reading's research outputs online 


\title{
Sick Building Syndrome: Are We Doing Enough?
}

\author{
Amirhosein Ghaffarianhoseini ${ }^{1}$, Husam AlWaer ${ }^{2}$, Hossein Omrany $^{3}$, Ali Ghaffarianhoseini ${ }^{1}$, Chaham \\ Alalouch $^{4}$, Derek Clements-Croome ${ }^{5}$, John Tookey ${ }^{1}$ \\ ${ }^{l}$ Department of Built Environment Engineering, School of Engineering, Auckland University of Technology, Auckland, New \\ Zealand \\ ${ }^{2}$ School of Social Sciences (Architecture \& Planning), University of Dundee, Dundee, UK \\ ${ }^{3}$ Faculty of the Professions, School of Architecture and Built Environment, The University of Adelaide, Adelaide, Australia \\ ${ }^{4}$ Department of Civil and Architectural Engineering, Sultan Qaboos University, Oman \\ ${ }^{5}$ School of the Built Environment, University of Reading, Reading, UK
}

\begin{abstract}
Health and wellbeing are vitally important aspects of people centric building design and are the roots of productivity. Sick building syndrome (SBS) is a collection of factors that can negatively affect physical health in several ways. Besides physical health is also related to psychological wellbeing because the human body is one interactive biological system. This paper focuses on reviewing the current state of knowledge on building sickness syndrome which has been prevalent as a building illness since the 1970s especially in offices and schools. While the concepts of intelligent, smart and sustainable buildings have gained considerable attention during recent decades, there is now increasing attention being given to designing healthy buildings.

Exposure of occupants to unhealthy indoor conditions increases their risk of illness and this influences their wellbeing. The prevalence of SBS can result in a wide array of concerns which affect the occupants' health and hence their work performance. This study endeavors to provide a holistic review of background knowledge about SBS symptoms. Several negative effects of SBS are identified and potential solutions are advocated. Finally, the study stresses the role of built environment and concludes that ongoing research towards tackling SBS and developing healthy indoor environments should not be limited to a single formula as any health-related building design approach is dependent on several interacting factors.
\end{abstract}

Keywords: Healthy Buildings; Sick Building Syndrome (SBS); Indoor Environments; Well-being; Sustainability

\section{Introduction}

Attitudes to well-being and healthy environments are beginning to change, both within the government and society, with a shift away from the idea that a flourishing life is primarily connected to material prosperity towards one that positions well-being as a significant goal for public policy (Barton, et.al, 2010; Barton, 2016; AlWaer and Illsley, 2017). This shift is being accompanied by a commitment to the design of healthy environments that would encourage productive workplaces, occupants' health and improvement of natural environments/ecosystems. Together, these changes provide opportunities to secure healthier lifestyles, sustain urban development, safeguard ecological-integrity, promote greater equity and support more resilient places in the low carbon future (Barton, et.al, 2010; AlWaer and Illsley, 2017).

Recently, development of greener and smarter buildings, through the application of innovative technologies, has seen growing interests. Future buildings, embracing intelligent, smart, green and responsive attributes, have become a common topic of various academic debates, research investigations and practical implementations related to the architecture, engineering and construction industry. Besides, recent studies have focused on the sustainable dimension of buildings, their embodied intelligence, and responsive potentials as well as their contribution to smart cities (Ahvenniemi, et al., 2017; Bibri and Krogstie, 2016; Martos, et al., 2016; Yang, et al., 2016; Alalouch, et al., 2016). This study reviews the increasing attention to the impacts of buildings on health and well-being of occupants (Gens, et al., 2014; Li, et al., 2017; Park, et al., 2016; Clements-Croome, 2018). Nevertheless, it should be argued that rather than using a deterministic approach (as currently used for green buildings), a more transactional model could be useful for human building interactions. Having said that, healthy buildings are a good example of a 'wicked problem' - one that defies a clear definition, has contradictory elements, concerns a multiplicity of stakeholder 
views, and is difficult to solve (Churchman, 1967). Faced with the complexity of these contending forces, there is no single paradigm around based on which to organise thought and action towards a resolution for such concern. Instead, there are competing view-points about how to deliver better and healthier buildings, and indeed about how much priority should be given to them.

Nonetheless, this study argues that; the majority of recent attempts, both in practice and academia, by architects, engineers and designers, are limited to the latter area of focus. Hence, less attention has been paid to evaluating the crucial impacts of SBS on occupants' well-being, health status and productivity. Furthermore, for long, an ideal representation of future buildings was repeatedly shaped to embrace green and intelligent attributes while being intertwined with sophisticated automated and ICT-based technologies (Clements-Croome, 2008; Capeluto and Ochoa., 2017; Ghaffarianhoseini, et al., 2016; Lilis, et al., 2016). Despite these common technology-oriented viewpoints, only a limited amount of studies (with limitation to indoor environmental quality (IEQ) have attempted to define and envisage future buildings from the SBS perspective as being more responsive to occupants' behavior, preferences, health, social and psychological well-being.

SBS has attracted world wide attention from the public and research comunities, not least because of the rise in cases of overheating, inadequate ventilation and poor indoor air quality, and growing global awareness of the role of the built environment on human health. This paper evaluates the state of knowledge on SBS by providing a holistic understanding of the impact of SBS on occupant health, wellbeing and productivity; the factors that contribute to these symptoms; and potential solutions. The paper provides useful synthesis and visualisation of research on SBS contributors (SBS contributor = factors that contribute to SBS), mitigation strategies, and the evolution of healthy building design (in light of recent technological advances), that will undoubtedly be of interest to researchers in the fields of public health, architecture, engineering, sustainability, and indoor performance of buildings.

\section{Method}

\section{1 Systematic Literature Review}

The study attempted to review and critically analyze the core SBS sympthoms, contributors and their potential impacts through an exploratory review approach. The study objectives were to firstly identify the contributors to SBS and then to explore the strategies for mitigation and lastly to speculate about the use of healthy buildings to deal with SBS.

In this regard, using systematic literature review following preferred reporting items for systematic reviews (Moher, et al, 2009), a comprehensive literature search based on the 'title/ abstract/keyword' components was carried out. The keywords used in the literature search were generally wide ranging and included terms related to 'sick building syndrome (SBS)', 'healthy buildings', 'indoor environments', 'well-being', 'occupants' health' and 'sustainability' based on the available academic journal databases. The search process to retrive the relevant SBS studies also covered: 'SBS contributors', 'SBS sympthoms', and 'SBS mitigation'. The databases included: Web of Science, Google Scholar, Scopus, Proquest, ACM digital library and Sciencedirect. Likewise, exploring the list of references of the already found articles, few papers not covered in the above databases, yet considerably important for the review, were identified. Using various search engines to explore the literature assured that the weakness of one source can be covered by the strength of another. In addition, a grey literature search was conducted through Google's general search engine, using similar search terms with the aim of identifying relevant unpublished materials, government reports, and policy statements related to SBS. During this review approach, a collection of over 200 articles were identified and classified while through employing content analysis, all collected data were critically analyzed. This paper uses the issues identfied to call for a future agenda based on improving professional practice, as well as preparing the ground for more detailed research work in this field. It does not present answers and solutions to all the downsides of trying to reconceptualise the practice of SBS. Nor does it test the proposed framework against real projects or case studies. This study was generally limited to the identification and demonstration of the crucial impacts of SBS from built environment perspectives (limited to building specific factors) and the review aimed at identifying challenges for design/research plus providing new insights regarding the speculation of healthty living environments from SBS phenomena. The analysis identified the contributors to SBS and developed the matrix for mitigation through an evaluation of the complexity and effectiveness of mitigation strategies.

\section{2 Content Analysis}

The content analysis aimed to initiate a re-conceptualization of SBS that offers an analytic framework for more systematic enquiry. The outcome of preceding step was 220 sources identified across the literature for inclusion in the study, to which they had been meticulously read to proceed with a qualitative content analysis. The acquired 
information concerned with various aspects of SBS were initially recorded into a spreadsheet, organized by several columns corresponding to 'Overview of SBS', 'SBS Contributors', 'SBS Symptoms', and 'Mitigation Strategies'. The adoption of this research approach enabled the authors to systematically explore the existing body of literature, retrieve the relevant information and highlight the gap of knowledge using coding approach, as demonstrated in the concluding sections. During the content analysis, notwithstanding the extensiveness of the collected data and synthetic process of analyzing their embedded info relevant to the objectives of study, a number of limitations can be highlighted. First, the collected data and the content analysis were limited to the utilized search engines, databases and applied research terms. Second, the study was limited to the exploration of existing studies to identify SBS contributers, mitigation approaches and the relevance to healthy buildings.

\section{Sick Building Syndrome \\ 3.1 Introductory Overview}

The concept of SBS was initially developed by the World Health Organization (WHO) in 1983 (Lim, et al., 2015; WHO, 1983). In the definition presented by WHO, SBS has been defined as 'a collection of nonspecific symptoms including eye, nose and throat irritation, mental fatigue, headaches, nausea, dizziness and skin irritations, which seem to be linked with occupancy of certain workplaces' (WHO, 1983). Later, the Commission of the European Communities published a report titled "Sick Building Syndrome: A practical Guide" emphasizing the severity of the negative effects of the phenomenon (Molina, 1989). In another definition presented by Greer (2007), SBS has been defined as 'a group of non-specific symptoms with a temporal connection to a particular building, but with no specific or obvious cause'. To this end, Murphy (2006) points out that symptoms of SBS are mainly minor, being varied with each episode of exposure. Similarly, Transport Salaried Staffs' Association (TSSA) (2010) in the UK defined SBS as 'a generic term used to describe common symptoms which, for no obvious reason, are associated with particular buildings'. Gomzi and Bobić (2009) describes SBS as 'an environmentally related condition with increased prevalence of non-specific symptoms among the population of certain buildings, often without clinical signs and objective measures of symptoms'. From another perspective, SBS has been defined as 'the density of workers' complaints', in which the WHO defined this density to be $20 \%$ of the building occupants presenting with the symptoms of SBS (Jansz, 2011a). In fact, the first reports of health and comfort complains among building occupants of artificially ventilated buildings started to pop up in the literature during 1970's (Graudenz, 2011). Similarly, other related studies stressed that there are two main criteria for the existence of SBS in a building: a) at least $20 \%$ of buildings users are concerned about an identical medical problem $b$ ) that identical medical problem is observed for at least 2 weeks (Abdul-Wahab, 2011; Clements-Croome, 2018). Table 1 demonstrates various definitions extracted from the literature.

Table 1. SBS definitions

\begin{tabular}{|c|c|c|}
\hline Reference & Definition & Key Attributes \\
\hline WHO (1983) & $\begin{array}{l}\text { A collection of nonspecific symptoms including eye, nose } \\
\text { and throat irritation, mental fatigue, headaches, nausea, } \\
\text { dizziness and skin irritations, which seem to be linked with } \\
\text { occupancy of certain workplaces. }\end{array}$ & $\begin{array}{l}\text {-SBS symptoms } \\
\text { nonspecific. }\end{array}$ \\
\hline Rostron (2008) & $\begin{array}{l}\text { SBS is a syndrome of complaints covering nonspecific } \\
\text { feelings of malaise, the onset of which is associated with } \\
\text { occupancy of certain modern buildings }\end{array}$ & $\begin{array}{l}\text {-Direct correlation with the } \\
\text { occupancy in certain building. }\end{array}$ \\
\hline $\begin{array}{l}\text { Molina, et al. } \\
\text { (1990) }\end{array}$ & $\begin{array}{l}\text { SBS is the name given to a set of varied symptoms } \\
\text { experienced predominantly by people working in air } \\
\text { conditioned buildings, although it has also been observed in } \\
\text { naturally ventilated buildings. }\end{array}$ & $\begin{array}{l}\text {-The recognized symptoms are } \\
\text { similar amongst the group of } \\
\text { people residing in a certain } \\
\text { environment. }\end{array}$ \\
\hline EPA (1991) & $\begin{array}{l}\text { SBS is used to 'describe situations in which building } \\
\text { occupants experience acute health and comfort effects that } \\
\text { appear to be linked to time spent in a building, but no specific } \\
\text { illness or cause can be identified'. }\end{array}$ & $\begin{array}{l}\text {-The signs are nonspecific } \\
\text {-Direct relationship with the } \\
\text { occupancy in certain building. } \\
\text {-The appearance of same acute } \\
\text { symptoms amongst the } \\
\text { residents of a certain building. }\end{array}$ \\
\hline
\end{tabular}

Goldman (1996) SBS is where the occupants of a building are affected over an indefinite period, and is directly connected with the building itself.

-Building is the main source of SBS appearance. 


\begin{tabular}{ll}
\hline Greer (2007) & $\begin{array}{l}\text { A group of non-specific symptoms with a temporal } \\
\text { connection to a particular building, but with no specific or } \\
\text { obvious cause. }\end{array}$ \\
\hline Gomzi and & An environmentally related condition with increased \\
Bobić (2009) & $\begin{array}{l}\text { prevalence of non-specific symptoms among the population } \\
\text { of certain buildings, often without clinical signs and } \\
\text { objective measures of symptoms. }\end{array}$
\end{tabular}

Passarelli (2009) SBS is a range of non-specific illnesses that are experienced by an occupant while inside a particular building or within a specific area of the inside environment. The symptoms experienced usually disappear hours, or in some cases days, after the occupant is away from the enclosed environment.

$\begin{array}{ll}\text { TSSA (2010) } & \text { A generic term used to describe common symptoms which, } \\ & \text { for no obvious reason, are associated with particular } \\ & \text { buildings. }\end{array}$

Crook and SBS is a complex spectrum of ill health symptoms associated Burton (2010) with the indoor environment. In broad terms, these symptoms can be divided into mucous membrane symptoms related to eyes, nose and throat; dry skin; general symptoms of headache and lethargy. These symptoms should improve within hours of leaving the problem building.

Jansz (2011a) SBS is the density of workers' complaints', in which the WHO defined this density to be $20 \%$ of the building occupants presenting with the symptoms of SBS

Imai and Imai SBS symptoms are related to the environments, with a focus (2011) on chemical exposure and indoor moulds, where mucosal symptoms and general symptoms such as headache, dyspnoea, loss of consciousness, and visual disturbance start appearing shortly after people move into a new house or into a remodeled house.

Jansz (2011b) SBS is a clinical diagnosis without any cause, or causes,
being specifically identified

Abdul-Wahab SBS is referred to scenarios where over $20 \%$ of buildings

(2011);

Clements-

Croome (2018) users are concerned about a similar medical issue while being in the building as a result of an unidentified reason during a minimum cycle of 2 weeks.

Takigawa et al. SBS is characterized by various nonspecific subjective (2012) symptoms, including irritation of the eyes, nose, and throat, headache and general fatigue, in rooms with deteriorated indoor air quality.

Norhidayah, et al. (2013)

SBS is the exposure of common symptoms amongst certain individuals working or living in an environment, where the appearance of these signs depends on their presence in that place.

Shan et al. SBS is a group of symptoms related but not limited to the (2016) SBS is a group of symptoms related but not limited to the
irritation of the eyes, nose, throat, skin, breath, and other general symptoms such as headache and lethargy that temporally occur among occupants of a certain building
-The causes are indefinite.

-Symptoms are nonspecific and transient.

-The symptoms are

nonspecific.

-The signs are prevalent amongst the occupants residing in a certain building.

-Majority of these signs are not clinical.

-The symptoms are nonspecific -The environment is the main cause of appearing SBS.

-The symptoms will be improved once the occupants leave the place.

-The symptoms are nonspecific -The main cause of appearing SBS signs is the building itself. -The main cause of appearing SBS signs is the building itself. -Signs will be improved once users leave the building.

-The existence of SBS in a certain place can be quantified.

-The main cause of SBS symptoms is the building itself. -The SBS symptoms can be even manifested in new house or into a remodeled house.

-The signs of SBS are nonspecific.

- $20 \%$ of building occupants and at least 2 weeks to be considered SBS.

-SBS symptoms are

nonspecific

-SBS symptoms may concern certain parts of the body.

-SBS symptoms prevail among occupants of a certain building. -The building is the main cause for appearing the SBS signs.

-The extent of SBS signs cannot be limited.

-These symptoms are temporal 
The common characteristic that is frequently repeated amongst the presented definitions is the 'non-specific' essence of SBS symptoms. This indicates that the signs of SBS can be highly variable, affecting diverse parts of human body in which correlating them to SBS could be challenging in the first place. Nonetheless, several health-related symptoms can be associated with SBS including: i) general symptoms (i.e. hoarseness of voice, allergies, flulike symptoms, respiratory diseases, nausea, dizziness, headache, fatigue, and inability to concentrate), ii) mucous symptoms (i.e. eye, throat and nose irritations or coughing) and iii) dermal symptoms (i.e. itching skin, face, hands or scalp) (Amin, et al., 2015; Lim, et al., 2015; Lu, et al., 2016; Shan, et al., 2016). The negative effects of SBS are interconnected, as the occurrence of one effect can lead to the manifestation of another. Majority of the discussed SBS's effects can negatively affect the occupants' well-being. Amin, et al (2015) investigated thermal conditions and SBS symptoms in three air-conditioned engineering education laboratories of a university in Malaysia. The results showed that majority of students in each lab experienced all the SBS symptoms. Among the symptoms, dry skin received the highest percentage of contribution, followed by runny nose, dry eyes, blocked/stuffy nose, tiredness and flu-like symptoms. In another study, Jafari, et al. (2015) endeavored to assess the association of SBS with individual factors and indoor air pollutants among employees in two office buildings in Iran. They found that, the chief contributors of SBS amongst the employees were recycling of air in rooms using fan coils, traffic noise, poor lighting, and buildings located in a polluted metropolitan area. The most common symptoms found among the employees were malaise (a sense of discomfort) and headache. They also identified throat dryness, cough, sputum, wheezing, skin dryness and eye pain as other signs of SBS effects among the employees.

Notwithstanding the various determinants contributing to the emergence of SBS symptoms, this study classified major causes of SBS under two general categories: individual-related factors and ambiance-related factors.

Individual-related factors can be gender, history of atopy (genetic tendency towards developing allergic diseases)/allergic disorders, low status of individuals in an organization, working on more routine tasks and smoking status (Bullinger, et al., 1999; Lu, et al., 2016). Bachmann and Myers (1995) investigated the correlations between typical symptoms of SBS, musculoskeletal symptoms, psychological state, work stress and interpersonal relationships at work among 624 office workers in three buildings. It was stated that psychological state is among the key predictors of symptoms. Furthermore, Sahlberg, et al. (2009) identified smoking and indoor painting as the two potential predictors of SBS symptoms through conducting an 8-year follow-up period to investigate the changes of SBS and different types of indoor exposures at home.Runeson-Broberg and Norbäck (2013) studied the association between SBS symptoms and physical and environmental conditions at both home and work through distributing postal questionnaire. Their findings confirmed the positive association existed between the perceptions of poor physical environmental conditions and emergence of common medical symptoms. They stated that atopy, poor air quality at work, and low social support, especially low supervisor support, were significantly associated with both SBS symptoms at work and home.

However, the prevalent complaints of SBS are more likely to be related to the ambient issues, including building dampness (Lu, et al., 2016; Norbäck, et al., 2016). Building dampness is the presence of unwanted moisture in the building structure, which can be either the result of intrusion from outside or condensation within the structure. This phenomenon may stimulate the appearance of respiratory illness such as asthma in occupants (Choi, et al., 2017; Norbäck, et al., 2017; Wang, et al., 2017). Takeda, et al. (2009) identified dampness as one of the critical factors associated with SBS symptoms in newly built dwellings. Similarly, Zhang, et al. (2012) identified the damp and moldy environment as a simulator for occurrence of SBS symptoms, as the presence of occupants in these environments can increase the incidence of work-related symptoms, whilst the possibility for remission may decrease. In damp buildings, mold and bacteria grow by enjoying the hospitable environment existing in settled dust (Lim, et al., 2015). Endotoxin (found in the outer cell membrane of gram-negative bacteria) (Gehring, et al., 2008) and (1,3)- $\beta$-glucan (found in the cell-walls of mold) (Iossifova, et al., 2007) are the two common compounds living in building dampness, causing proinflammatory effects (Lim, et al., 2015). Given these explanations, it can be inferred that the level of seriousness and the period of emerging symptoms once the occupants are exposed to sick environments can be highly variable. This mainly depends on the level of exposure and susceptibility of occupants to environmental contaminants (Jansz, 2011b).

SBSs were found across the world in different building types. Table 2 presents a summary of a selected set of studies from different countries that investigated SBS. Therefore, literature indicates the significant impacts of SBS on occupants. These symptoms may result in affecting the residents' well-beings, or diminishing their productivities rates once they are working. Majority of these symptoms are found to be transient and their effects will be dissipated when 
the occupants leave the place such as work-related symptoms (Lim, et al., 2015; Tsai, et al., 2012; Zhang, et al., 2011), though some of these symptoms can have a long-lasting effects on residents' health namely respiratory-related issues (Crook and Burton, 2010; Zhang, et al., 2012). In order to better understand SBS, the following sections review the major causes of SBS and their negative effects aiming at assisting practitioners to be familiarized with the effects of SBS and its relative symptoms as well as how to mitigate its effect on the occupants.

Table 2. Studies addressed the impacts of SBS on human wellbeing

\begin{tabular}{|c|c|c|c|}
\hline Author (s) & Country & Type of Building & Identified Symptoms associated with SBS \\
\hline (Magnavita, 2015) & Italy & Companies & $\begin{array}{l}\text { Anxiety, depression, } \\
\text { discomfort and job strain }\end{array}$ \\
\hline (Jafari, et al., 2015) & Iran & Office buildings & $\begin{array}{l}\text { Malaise, headache, throat dryness, cough, } \\
\text { sputum, wheezing, skin dryness and eye pain }\end{array}$ \\
\hline (Zhang, et al., 2014) & China & Schools & Skin symptoms, mucosal symptoms \\
\hline (Shan, et al., 2016) & Singapore & Schools & Head and eye related issues \\
\hline (Norbäck, et al., 2016) & Malaysia & Schools & $\begin{array}{l}\text { Ocular, rhinitis, throat symptoms, headache } \\
\text { and tiredness, dermal symptoms. }\end{array}$ \\
\hline (Lim, et al., 2015) & Malaysia & University & Dermal, mucosal and general symptoms \\
\hline (Amin, et al., 2015) & Malaysia & University & $\begin{array}{l}\text { Dry skin, runny nose, dry eyes, blocked/ } \\
\text { stuffy nose, tiredness and flu-like symptoms }\end{array}$ \\
\hline (Sun, et al., 2013) & China & Dormitory & $\begin{array}{l}\text { General symptoms of sick building, mucosal } \\
\text { or skin problems and nose irritation }\end{array}$ \\
\hline (Sahlberg, et al., 2013) & $\begin{array}{l}\text { Sweden/Estonia/ } \\
\text { Iceland }\end{array}$ & $\begin{array}{l}\text { Residential } \\
\text { Building }\end{array}$ & $\begin{array}{l}\text { General signs of sick building (i.e. mucosal } \\
\text { symptoms) }\end{array}$ \\
\hline $\begin{array}{l}\text { (Takigawa, et al., } \\
\text { 2010) }\end{array}$ & Japan & $\begin{array}{l}\text { Residential } \\
\text { Building }\end{array}$ & Optical, nasal, and gular symptoms \\
\hline (Tsai, et al., 2012) & Taiwan & Office building & $\begin{array}{l}\text { Eye irritation and upper respiratory } \\
\text { symptoms }\end{array}$ \\
\hline al., 2016) & USA & Offic & Asthma and allergic disease \\
\hline (Gomzi, et al., 2007) & Croati & Office bu & Fatigue, sore and dry eyes, and headache \\
\hline $\begin{array}{l}\text { (Runeson-Broberg and } \\
\text { Norbäck, 2013) }\end{array}$ & Sweden & Office buildings & $\begin{array}{l}\text { Headache, tiredness, nausea, and sensation of } \\
\text { a cold }\end{array}$ \\
\hline
\end{tabular}

\subsection{SBS Contributors, symptoms and effects}

According to WHO, up to $30 \%$ of new and remodeled buildings worldwide were recognized to be potential carriers of SBS (Boubekri, 2008; Wong, et al., 2009). Since then, there have been many cases of SBS, predominantly in sealed office buildings. Although poor indoor environmental quality (IEQ) is often blamed for causing SBS, it is empirically challenging to substantiate or single out the main source(s) responsible for stimulating the appearance of a particular symptom. Reviewing the recent research investigations about SBS in buildings, the study draws attention to the major contributors of SBS as highlighted below:

- Physical contributors; These factors are associated with the physical attributes of buildings that can stimulate the appearance of SBS signs. These contributors can significantly affect the health status, well-being and comfort. In fact, the provision of physical comfort in a workplace is essential in enhancing the occupants' performances through encouraging a healthier and more productive workplace (Abdul-Wahab, 2011; Chua, et al., 2016; Leder, et al., 2016; Perrin Jegen and Chevret, 2016; Clements-Croome, 2008 and 2018).

- Temperature; Deviation from the thermal comfort threshold for buildings' indoor environment may result in occurrence of SBS (Humphreys, et al., 2015), while subsequently affecting the performance rates of individuals (Chua, et al., 2016; Fang, et al., 2004; Seppanen, et al., 2006; Wyon, 2004). Chua, et al. (2016) found a strong correlation existing between room temperature, lighting and relative humidity in one hand and health-related issues in the other. These caused difficulties in concentration and eventually affected the employees' productivity. Seppanen, et al. (2006) identified a direct link between workers' performances and temperature. It was shown that the performance increased with temperature up to $21-22^{\circ} \mathrm{C}$ and decreased with temperature above $23-24^{\circ} \mathrm{C}$. In a review of a 24 research paper on the effect of thermal comfort on productivity, Wargorcki, et al. (2006) found a $10 \%$ reduction in performance at both $30^{\circ} \mathrm{C}$ and $15 \mathrm{C}$ compared with a baseline between $21^{\circ} \mathrm{C}$ and $23^{\circ} \mathrm{C}$. Similarly, Vimalanathan and Babu (2014) conducted a 
neurobehavioral test experiment to explore the effect of indoor environment on workers performance. They concluded that an optimum level indoor room temperature on $21^{\circ} \mathrm{C}$ have improved the work performance, health and productivity of office workers.

- Humidity; The mechanism by which heat affects human performance is basically dependent upon interactions of a wide array of variables such as temperature, radiation, wind, and humidity, though it is often treated as a sole product of temperature (Davis, et al., 2016). Among these factors, the importance of humidity received a significant attention due to its direct link to human health. Although there is no agreement on what constitutes the ideal range of relative humidity, environments with temperature above $32^{\circ} \mathrm{C}$ and relative humidity above $60 \%$ are considered as hot and humid environment (Shi, et al., 2013). The existence of humidity can potentially provide a hospitable environment for microscopic organisms such as mildews and molds to be grown up indoor and pose a serious danger upon the health status of residents (Davis, et al., 2016). Additionally, humidity exposure can cause muscle cramps, fainting, heat stroke, and even exacerbate the underlying medical conditions, such as lung or heart disease (Zheng, et al., 2012). Wang, et al. (2013) investigated the prevalent perceptions of odors and sensations of air humidity and SBS symptoms in domestic environments through questionnaire distributed among 4530 parents of kindergarten children in China. The findings confirmed the significance of humid air's role in symptomizing general signs as well as mucosal and skin sicknesses in children.

- Ventilation; The current ventilation standards and guidelines (ASHRAE, 2007; ASHRAE, 2009) recommend a minimum ventilation rate of 8 litre/Second per person in order to extract the bio effluents (odors) (Bakó-Biró, et al., 2012). Poor ventilation can potentially trigger the emergence of SBS symptoms such as lowering the productivity rate, nose and throat irritation, headaches, fatigue, asthma, rhinitis and increased susceptibility to colds and flu (Annesi-Maesano, et al., 2012; Bakó-Biró, et al., 2012; Dimitroulopoulou, 2012; Sofuoglu, et al., 2011). Actions have been proposed to include adequate outdoor ventilation, control of moisture, and avoidance of indoor exposures to pollutants such as microbiological particles, allergens and chemical substances which are considered likely to have adverse effects. Bakó-Biró, et al. (2012) investigated the effects of classroom ventilation on pupils' performance in 8 primary schools in England by monitoring a number of parameters such as $\mathrm{CO}_{2}$ for three weeks in two selected classrooms. The results indicated that low ventilation rates in classrooms significantly reduce pupils' attention and vigilance, and negatively affect memory and concentration. In another study, Sundell, et al. (2011) stated that higher ventilation rates in offices, up to about $25 \mathrm{l} / \mathrm{s}$ per person, are associated with reduced prevalence of SBS symptoms, whereas the state of having lower ventilation rates contributes to causing symptoms such as inflammation, respiratory infections, asthma symptoms and short-term sick leave. Additionally, sufficient use of natural ventilation (NV) systems can be also considered as a promising strategy to tackle the SBS. Ideally, the air movement induced by buoyancy is capable of transporting heat and pollutants away from the occupied zone, promoting stratification, creating a warmed mixed layer in the upper part of the room. Studies also reported promising results for improving the health status of occupants where DV system was installed (Cheong, et al., 2006; Shan, et al., 2016). However, the usage of this system is involved in certain limitation. Mateus, et al. (2016) stated that DV systems require a height difference between inflow and outflow in order for the buoyancy forces to be effective, in which is difficult to achieve without using chimneys. For single story buildings chimneys can be placed in the roof, any other configurations require internal voids or individual chimneys that may be difficult to integrate in the target building.

- Illuminance level; The poor quality of light can directly influence human health by affecting the occupants' visual comforts. First, light influences the suprachiasmatic nucleus (SCN), a region in the hypothalamus that controls circadian rhythms, through the eye and the retinohypothalamic tract. Second, light inhibits the secretion of melatonin and result in disrupting of sleep pattern. Third, light is found to have alerting effects through indirect projections on the ascending arousal system, which in turn, facilitates thalamic and cortical connections (Berson, et al., 2002; Cajochen, 2007; van Maanen, et al., 2016). In addition, the poor status of lighting may potentially result in increasing the possibility for occurring the hazardous events, lowering occupants' performances, and having a negative effects on the occupants' eyes (Glen, et al., 2016). The importance of indoor illuminance was highlighted by Hwang and Kim (2010)'s research, where they investigated the effects of indoor lighting on occupants' visual comfort and eye health amongst 2744 workers in Korea. The findings indicated that daylight can potentially improve the occupants' psychological health and productivity. Illumination level at 1000lux were found to improve productivity, performance and occupant's health in office buildings (Vimalanathan and Babu, 2014).

- Noise; Noise is a pervasive and influential source of stress with great potentials to distract occupants engaged in undertaking a particular performance (Takki, et al., 2011). Noise effects are generally categorized into 
two broad groups; auditory (noise-induced hearing loss) and non-auditory (behavioral and physiological effects) (Basner, et al., 2014; Seidman and Standring, 2010). It is more likely that low frequency noise (20$100 \mathrm{~Hz}$ ) which is found in buildings with industrial machines or ventilation machinery may cause health problems (Bluyssen, et al., 2011). Noise exposure during night can lead to serious health effects on longterm, such as behavioral problems and cardio vascular effects (Bluyssen, et al., 2011). Moreover, it may affect the occupants' hearing abilities, increased systolic blood pressure and chronic headaches (Ismaila and Odusote, 2014; Khaiwal, et al., 2016; Li, et al., 2016). Wong, et al. (2009) studied the relationship between human health and environmental quality through investigating the prevalence of SBS among 748 households and their evaluation of IEQ in Hong Kong. It was shown that nasal discomfort was the most common homerelated SBS symptom despite the absence of any central ventilation system in apartment buildings. Furthermore, noise rather than ventilation, was the major IEQ problem perceived by residents.

- Air quality; The quality of indoor air can be affected by various factors, such as inappropriate selection of indoor materials or HVAC systems (based on their excessive $\mathrm{CO}_{2}$ concentrations). This can provide a hospitable environment for growing airborne bacteria and fungi, and subsequently, results in increasing the possibility for respiratory diseases, namely asthma (Bonetta, et al., 2010). Poor quality of indoor air can directly influence the residents' health and their performances (Pegas, et al., 2011). de Magalhães Rios, et al. (2009) investigated the association between the prevalence of work-related symptoms and the indoor air quality by comparing a sealed office building with a naturally ventilated building. It was concluded that symptoms such as eye dryness, runny nose, dry throat and lethargy were more prevalent in the sealed building. In another study, Gupta, et al. (2007) investigated the impacts of indoor air quality(IAQ) on the prevalence of SBS symptoms among the office employees in New Delhi, India. Quantitative analysis of IAQ was conducted by monitoring the indoor concentrations of four pollutants, namely, nitrogen dioxide $\left(\mathrm{NO}_{2}\right)$, Sulphur dioxide $\left(\mathrm{SO}_{2}\right)$, suspended particulate matter (SPM) and carbon monoxide $(\mathrm{CO})$. It was found that the prevailing symptoms were headache $(51 \%)$, lethargy $(50 \%)$, and dryness in body mucous $(33 \%)$. The results indicating a direct relation between the average SBS score and $\mathrm{CO}_{2}$ concentration was found, i.e., the average SBS score increased with $\mathrm{CO}_{2}$ concentration and vice versa. Additionally, $\mathrm{CO}_{2}$ and $\mathrm{RH}$ were positively associated with new onset of mucosal, general and school-related symptoms. This was generally supported by Satish, et al. (2012) who conducted lab-based study using simulated decision-making. The results suggested that $\mathrm{CO}_{2}$ having a significant detrimental impact at 1000 parts per million (ppm) compared to $600 \mathrm{ppm}$, despite $1000 \mathrm{ppm}$ being widely considered acceptable.

- Electromagnetic radiation (ER); The electromagnetic spectrum refers to a group of distinct forms of energies emanating from multiple sources with various frequencies (Genuis, 2008). The high frequencies are gamma rays, X-rays and ultraviolet light; the lower frequencies of the spectrum include microwaves; medium frequencies include radio waves and light wave emission that provide the possibility to perceive the vision and the light and infrared energy which allows perceiving the heat (Genuis, 2008). Ionizing radiation is a term to describe the human exposure to the sources of energy with high frequencies which results in causing serious health issues (Christensen, et al. 2014; Azzam, et al. 2012). This phenomenon may intrigue the risk of malignancy or cell death by altering the atomic composition of cell structures, breaking the chemical bonds and inducing free radical formation (Genuis, 2008; Azzam, et al. 2012). Fife (2017) mentioned that 'electromagnetic energy surrounds and penetrates our homes, our work environment and every place-inbetween'. In this regards, Zamanian and Hardiman (2005) stated that human beings are constantly exposed to low levels of ionizing radiation from natural sources such as sunlight, radioactive materials on the earth's surface, radioactive gases leaking from the earth, cosmic rays from outer space entering the earth's atmosphere through the ionosphere and natural radioactivity.

The natural radioactivity has been around since the beginning of universe due to the found radioelement in the earth's crust. The radionuclides of ${ }^{226} \mathrm{Ra},{ }^{232} \mathrm{Th}$ and ${ }^{40} \mathrm{~K}$ can be almost found in all types of rocks, granite, sand, cement and gypsum, from which majority of building materials are produced (Mavi and Akkurt, 2010). As such, materials obtained from the earth's crust contain traces of ${ }^{238} U$ and ${ }^{232} \mathrm{Th}$ (Bavarnegin, et al. 2013). In the ${ }^{238} \mathrm{U}$ series, ${ }^{226} \mathrm{Ra}$ decays to radon $\left({ }^{222} \mathrm{Rn}\right)$, which is a radioactive gas with a half-life of 3.82 days (Bavarnegin, et al. 2013; Lu, et al. 2012; Baykara, et al. 2011). Prolonged exposure of occupants to the indoor radon causes pathological effects and functional respiratory alterations, by which consequently lead to serious risks of developing lung cancer (Bavarnegin, et al. 2013; Saad, et al. 2014). The severity of this risk depends on the concentration of radon indoors, the duration of exposure, and the degree of ventilation in the houses (Saad, et al. 2014). To this extent, the significance of addressing the exposure of human beings originating from the building materials has been underlined by several initiatives. For instance, the article 
75 of the Euratom basic safety standards (EU-BSS) (Council directive 2013/59/Euratom) stipulated that, 'the reference level applying to indoor external exposure to gamma radiation emitted by building materials, in addition to outdoor external exposure, shall be 1 MilliSievert (mSv) per year' (European Council, 2014). EU-BSS is expected to be transposed to national law by EU Member States before February 2018, aiming to establish a basic standard adoptable by the EU members to protect the public against the exposure of ionising radiation (Croymans, et al. 2018; Schroeyers, et al. 2018). Studies have widely addressed the issue associated with the emission of natural radioactivity from building materials (Mavi and Akkurt, 2010; Chen, et al. 2010; Saad, et al. 2014; Bavarnegin, et al. 2013; Lu, et al. 2012; Ravisankar, et al. 2012). In one attempt, Mavi and Akkurt (2010) measured the radioactivity of commonly-used building materials, namely brick, cement, limestone, ytong, limra, gypsum, ceramic tile and gravel existing in Ispartacity of Turkey. They conclusively stated that the levels of natural radioactivity in these materials were below the acceptable limits. Saad, et al. (2014) also assessed the rates of radon exhalation concerned with 37 samples of different building materials which were being utilized for the purposes of construction and decoration in Libyan market. The results identified two materials, Indian granite and Italian marble, with high values of radon concentration, in which have been recommended to be substituted by alternatives.

- Biological contributors; IAQ can be affected by development of moulds, fungi and mites inside the buildings and endanger the occupants' wellbeing and health status. Several contributors can be mentioned with the association to the growth of biological factors inside the buildings namely, building's structural failure, poor air ventilation or improper maintenance of building (Johansson, et al., 2013; Vereecken and Roels, 2012). Consistent exposure of residents with these infected environments can result in occurring health-related issues such as respiratory and allergic diseases (Singh, 2005; Singh, et al., 2010). Sun, et al. (2013) carried out a research to investigate the dorm environment and college students' health in Tianjin, China. They found that local moldy odor was a significant risk factor for nose irritation. Since 2004, the development of quantitative polymerase chain reaction (QPCR) analysis of molds (US. Patent $6,387,652$ ) has dramatically improved fungal speciation and quantification, resulting in a highly standardized process for describing the indoor fungal population (EPA, 2004; Vesper and Vesper, 2004). Recently, studies are focused on identifying the significance of biological attributes, namely fungi that can potentially contribute to SBS. In one attempt, Boechat, et al. (2011) investigated the prevalence of SBS in workers of two buildings and its relationship with fungal exposure in the workplace in Rio de Janeiro, Brazil. Based on the medical examination and a score-based questionnaire, they evaluated the SBS diagnosis of 160 full-time workers of a sealed building, and 164 employers from a naturally ventilated building. The results indicated that the prevalence of SBS in the sealed building and non-sealed buildings were $44.8 \%$ and $48.6 \%$, respectively. They stated that, fungi exposure was the unique significant risk factor for SBS in the non-sealed building, whilst no significant exposure to fungi in the indoor environment of the sealed building was found. Polizzi, et al. (2011) also announced that the 6-pentyl-2-pyrone produced by $T$. atroviride, a mold present in damp dwellings, can result in the appearance of SBS symptoms. The 6pentyl-2-pyrone is a compound emitted on common building materials that could give irritation and damage to mucosal membranes.

- Chemical contributors: Certain chemical substances and dust could lead to developing SBS. For example, Sahlberg, et al. (2013) examined the association between volatile organic compounds (VOCs) of possible microbial origin (MVOCs), and airborne levels of bacteria, molds, formaldehyde, and two plasticizers in dwellings with the prevalence of SBS. This study was conducted with participation of 159 adults selected from three cities in Sweden, Iceland and Estonia. The conclusion confirmed the existence of a positive association between MVOCs, formaldehyde and the plasticizer texanol with appearance of symptoms of sick buildings, namely mucosal symptoms. On the other hand, Takigawa, et al. (2010) investigated the possible relationship between chemical substances and SBS symptoms of residents living in newly constructed houses in Japan. The results demonstrated the positive association between existence of VOCs and aldehydes with optical, nasal, and gular symptoms. They concluded that chemicals detected in Japanese newly built houses tend to increase the risk of subjective symptoms in residents suffering from SBS. In another study Sahlberg, et al. (2009) investigated the changes of SBS and different types of indoor exposures at home for the period of 8 years. They concluded that indoor painting is one of the major to SBS. In addition, the presence of fine dust was found to be associated with SBS (Lim, et al., 2015). Norbäck, et al. (2016) studied the appearance of SBS among 462 students at secondary schools in Johor Bahru, Malaysia. The results confirmed a positive association between the existence of fine dust in the classroom and appearing of some symptoms of sick buildings i.e. ocular symptoms and rhinitis. Furthermore, there were positive associations between $\mathrm{C} 143-\mathrm{OH}$ and rhinitis and between C18 3-OH and dermal symptoms. 
- Psychosocial contributors: SBS can pose serious threats on occupants' psychosocial status through subjecting them with anxiety, depression, environmental discomfort, job strain and reducing the occupants' performances. One of the psychosocial factors that is believed to be effective in the development of SBS is monotonous work environment. Monotonous work refers to the state that the employees are obligated to constantly repeating activities or tasks (Gül, 2011). This can result in degrading the productivity rate of employees as they may become mentally disengaged with their tasks. Additionally, Crawford and Bolas (1996) underlined the role of occupational stress to be closely correlated with appearance of SBS symptoms. Nevertheless, it should be argued that despite the significant impact of psychosocial contributor, the number of existing studies with focus on examining its impacts is relatively limited.

- Individual contributors: Personal characteristics of individual's might amplify the effect of SBSs on occupants. To explain, gender, genetic tendency to develop allergy, smoking status and psychological state were found to be associated with SBS (Bachmann and Myers, 1995; Bullinger, et al., 1999; Lu, et al., 2016). In one study, Lim, et al. (2015) investigated the associations between SBS symptoms, selected personal factors, office characteristics and indoor office exposures among office workers from a university in Malaysia. It was concluded that a combination of allergy to cat or house dust mites is a risk factor for SBS. On the other hand, Zhang, et al. (2011) conducted a twoyear study investigating changes of SBS symptoms in Chinese pupils pertained to the parental asthma/allergy, own atopy, classroom temperature, relative and absolute humidity, crowdedness, IAQ (i.e. $\mathrm{CO}_{2}, \mathrm{NO}_{2}$, and $\mathrm{SO}_{2}$ ). It was found that parental asthma/allergy and atopy were correlated with incidence of SBS.

The attributes causing SBS will not be limited to the mentioned contributors, other factors such as 'building materials', 'poor sanitation', 'availability of ozone, organic solvents and formaldehyde in the atmosphere', 'office equipment, furnishings and other materials and products located or used in the building with potentials to produce fumes or contact dermatitis', 'air borne chemical fumes or gasses from any components in the building' and 'vermin (i.e., mice, rats and cockroaches) infestation' can also play a significant role towards the unhealthy status of a building (Jansz, 2011b; Bernstein, et al. 2008; Singh, et al. 2010; Petry, et al. 2014). In a study, Lee, et al. (2001) employed a test chamber to characterize the rate of pollutants introduced from certain office equipment, namely fax machines, laser printers, inkjet printers, scanners and photocopying machines. They measured the concentrations of VOCs, total VOC (TVOC), ozone, respirable particles (PM10) and temperature associated with the usage of these equipment. The results indicated that the highest emission rates of VOCs compounds were toluene, ethylbenzene, m,p-xylene, and styrene. Also, the emissions of ozone and VOC produced through the laser printers were significantly higher than ink-jet printers. In another study, Kowalska, et al. (2015) analyzed the indoor emissions of volatile halogenated organic compounds (VHOCs) produced through office printers and copiers by taking samples in laboratory conditions during the operation of these appliances. The tests of VHOCs were performed by dint of utilizing a simulated environment (test chamber). The results showed that, the operation of these devices can significantly lead to producing VOCs in typical office indoor air. Furthermore, the chlorinated organic compounds were the only determinants found amongst the examined VHOCs, which may possibly contribute to carcinogenic.

Table 3 summarizes the major effects of each contributor on the occupants' well-being. It can be conclusively mentioned that attributes pertained to the physical features of buildings may have a more determinative influence in stimulating the emergence of SBS' symptoms. The negative impacts of physical contributors on occupants' health during the operational phase of building can be initially neutralized through considering health-related design principles during the building's design phase. The building's orientation (Abanda and Byers, 2016; Mangkuto, et al., 2016), felicitous selection of building materials in accordance with local climate (Mirrahimi, et al., 2016), application of passive techniques in building envelope such as passive walls (Omrany and Marsono, 2016; Bellos, et al., 2016; Omrany, et al., 2016) are some preliminary measures that can be taken during the design phase in order to preclude the occurrence of physical contributors.

Table 3. SBS Contributors

\begin{tabular}{|c|c|c|c|}
\hline \multicolumn{2}{|c|}{ Contributor } & \multicolumn{2}{|r|}{ Effects } \\
\hline 离 & Temperature & $\begin{array}{l}\text { Deviation from the thermal comfort } \\
\text { threshold (hot or cold). } \\
21^{\circ} \mathrm{C} \text { is recommended for better } \\
\text { performance and health. }\end{array}$ & Distraction, Lowering the rate of productivity \\
\hline
\end{tabular}




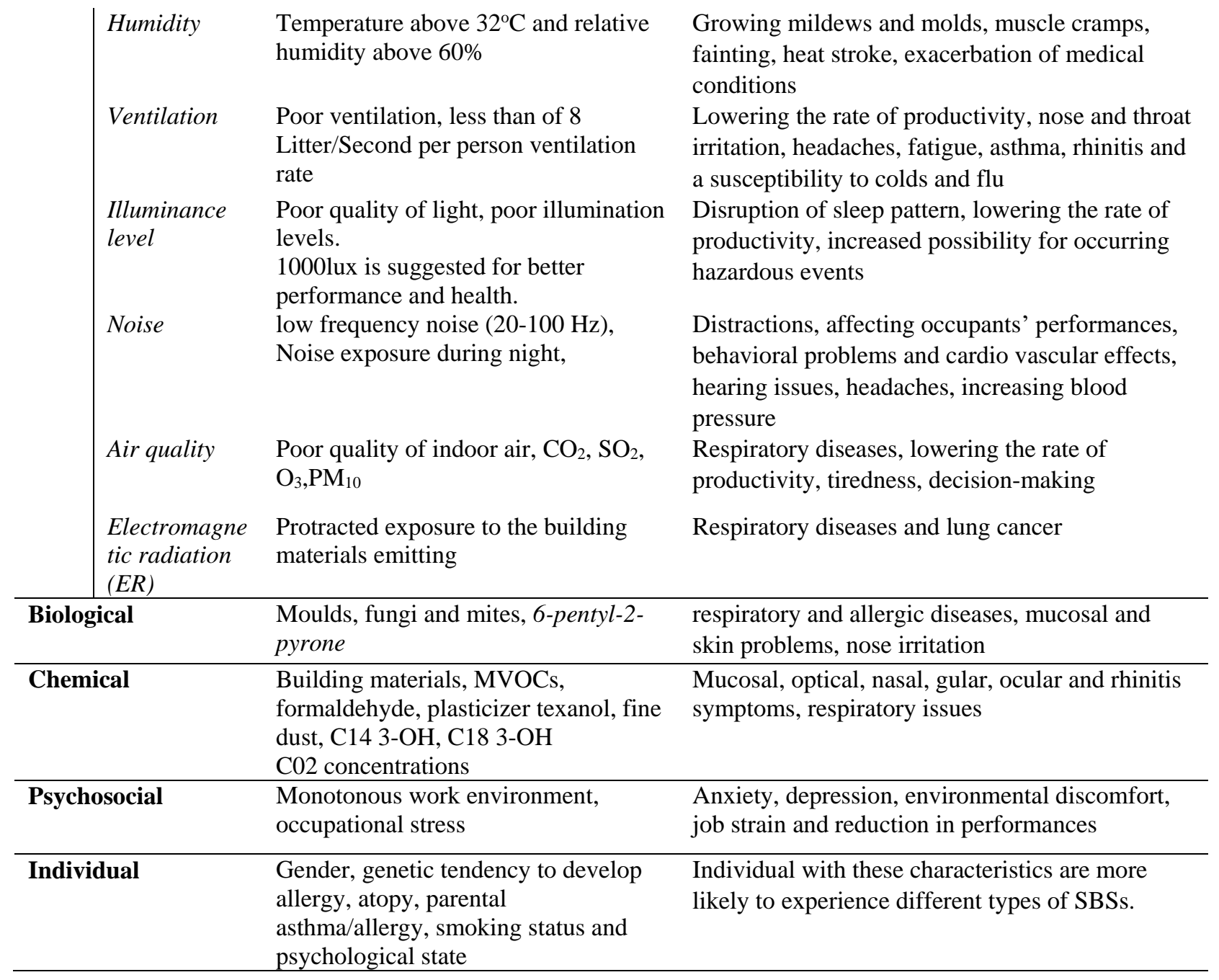

The occurrence of SBS can be recognized in various environments such as office spaces (Lim, et al., 2015; Magnavita, 2015; Tsai, et al., 2012), residential environments (Engvall, et al., 2010; Takigawa, et al., 2012; Takigawa, et al., 2010), schools (Norbäck, et al., 2016; Saijo, et al., 2010; Shan, et al., 2016; Takaoka, et al., 2016), universities (Ahmad and Hassim., 2015) or hospitals (Chang, et al., 2015; Loupa, et al., 2015; Wang, et al., 2015). The core symptoms of SBS may concern with the health status of occupants, either physically or mentally. These symptoms can potentially incur many negative effects on the occupants. Majority of these negative effects are interrelated, in which the occurrence of one effect may trigger the emergence of another (Vural and Balanl1, 2011; Abdul-Wahab, 2011).

\subsubsection{Symptomatology}

Recent studies (de Kluizenaar, et al., 2016; Lim, et al., 2015; Lu, et al., 2016) suggested several symptoms for SBS, affecting different parts of human body ranging from headache, fatigue and irritation in upper respiratory tract to nose, throat, eyes, and dermal abnormalities. These signs can be categorized into eight main groups (See Table 4):

Table 4. SBS symptoms

\begin{tabular}{lll}
\hline Category & Symptoms & Description \\
\hline Respiratory & Allergic Rhinitis (repetitive sneezing and a runny & It refers to the symptoms that concern the \\
& nose),Sinus congestion, Influenza like symptoms, & respiratory system of patients (Choi, et \\
& Dry Cough, Throat irritation, Wheezing when & al., 2017; Norbäck, et al., 2017).
\end{tabular}
breathing, Shortness of breath, Sensation of having dry mucus membranes, Hoarseness of the voice due to inflammation of the throat and 


\begin{tabular}{|c|c|c|}
\hline & $\begin{array}{l}\text { larynx, Sensitivity to odors, Increased incidences } \\
\text { of building related asthma attacks, Asthma }\end{array}$ & \\
\hline Nasal & $\begin{array}{l}\text { Runny nose, Sneezing, Blocked nose, Nose } \\
\text { bleeding }\end{array}$ & $\begin{array}{l}\text { One of the most frequent symptoms that } \\
\text { inhabitants of sick buildings suffer is the } \\
\text { nasal irritation with rhinorrhea and nasal } \\
\text { obstruction. This symptom which is } \\
\text { usually considered as 'nasal stuffiness' } \\
\text { may appear alongside the other factors } \\
\text { (Norbäck, et al., 2016; Norbäck, et al., } \\
\text { 2016; Takaoka, et al., 2016; Takki, et al., } \\
\text { 2011). }\end{array}$ \\
\hline Ocular & $\begin{array}{l}\text { Eye dryness, Itching of the eyes, Watering of the } \\
\text { eyes, Gritty eyes, Eye Burning, Visual } \\
\text { disturbances, Light sensitivity, Swollen eyelids }\end{array}$ & $\begin{array}{l}\text { It refers to the presence of issues related } \\
\text { to the dryness and irritation of mucous } \\
\text { membrane of eye and swollen eyelids } \\
\text { (Lu, et al., 2016; Norbäck, et al., 2016; } \\
\text { Sheikhmohammadi, et al., 2016; Zhang, } \\
\text { et al., 2012). }\end{array}$ \\
\hline Oropharyngeal & $\begin{array}{l}\text { Dryness and irritation of the throat, Dry sore } \\
\text { throat }\end{array}$ & $\begin{array}{l}\text { It refers to the presence of dryness and } \\
\text { irritation of the throat (Chang, et al., } \\
\text { 2015; Sheikhmohammadi, et al., 2016; } \\
\text { Zhang, et al., 2012). }\end{array}$ \\
\hline Cutaneous & $\begin{array}{l}\text { Skin rashes, Itchy skin, Dry skin, Erythema } \\
\text { (Redness or inflammation due to congestion in, } \\
\text { and dilation of, the superficial capillaries of the } \\
\text { skin.), Irritation and dryness of the lips, } \\
\text { Seborrheic dermatitis, Periorbital eczema, } \\
\text { Rosacca, Uritcaria, Itching folliculitis }\end{array}$ & $\begin{array}{l}\text { This is related to the appearance of } \\
\text { dryness and irritation of skin, which } \\
\text { occasionally associated with rashes } \\
\text { exposed on the skin surfaces (Lu, et al., } \\
\text { 2016; Maoz-Segal, et al., 2015). }\end{array}$ \\
\hline Lethargy & $\begin{array}{l}\text { Lethargy, Difficulty in concentrating, Mental } \\
\text { fatigue, General fatigue, Unable to think clearly, } \\
\text { Drowsy }\end{array}$ & $\begin{array}{l}\text { It refers to the emergence of symptoms } \\
\text { that cause the occupants feel laziness (de } \\
\text { Magalhães Rios, et al., 2009; Gupta, } \\
\text { 2007). }\end{array}$ \\
\hline Cognitive & $\begin{array}{l}\text { Functional headache that affect a person's } \\
\text { performance, but which fail to reveal evidence of } \\
\text { physiological or structural abnormalities, } \\
\text { Migraine headache, Tension headache, Sinus } \\
\text { headache due to swelling of the mucus } \\
\text { membranes, Mental confusion }\end{array}$ & $\begin{array}{l}\text { It refers to the manifestation of illness } \\
\text { that concern the occupants' } \\
\text { concentration (Lim, et al., 2015; Lu, et } \\
\text { al., 2016; Zhang, et al., 2012). }\end{array}$ \\
\hline General & $\begin{array}{l}\text { Nausea, Dizziness, Unspecified hypersensitivity } \\
\text { reactions, deteriorating the pre-existing illnesses } \\
\text { i.e., asthma, sinusitis or eczema. }\end{array}$ & $\begin{array}{l}\text { It refers to the general symptoms such as } \\
\text { nausea, unspecified hypersensitivity } \\
\text { reactions, exacerbation of pre-existing } \\
\text { illnesses such as asthma, sinusitis on } \\
\text { eczema. }\end{array}$ \\
\hline
\end{tabular}

\subsubsection{Psychological well-being and satisfaction}

Sick buildings can induce the appearance of psychological symptoms such as stress, anxiety and aggression in occupants (Kamaruzzaman and Sabrani, 2011; Runeson-Broberg and Norbäck, 2013). These psychological disorders may further result in increasing people' susceptibilities toward other environmental factors, lowering workers' performances and increase absenteeism (Realyvásquez, et al., 2016; Rydstedt, 2016). These negative psychological effects of being in sick buildings can further result in subsequent issues for occupants such as increasing the possibility for occurring the hazardous events in workplace. Likewise, SBS can also influence occupants' satisfaction. Gavhed and Toomingas (2007) counted poor illumination levels, besides indoor climate, the air quality, the ambient noise level, as the major contributors leading to dissatisfaction among Swedish employees. In another study, Newsham, et al. (2009) studied the effects of physical measurements such as thermal, lighting, and acoustic variables, furniture dimensions, and an assessment of potential exterior view on the employees' performances at an open-plan office 
building in Michigan, US. Results highlighted the significant role of window access at the desk in satisfaction with lighting, particularly through its effect on satisfaction with outside view.

\subsubsection{Productivity and Associated Costs}

The negative effects of sick buildings can be also regarded in terms of costs imposing upon occupants. These expenses may appear in various forms, namely absence from work, lower productivity, remedial expenses, or increasing the building energy consumption (Fisk, et al., 2011; Fisk, et al., 2012).The Carnegie Mellon's E-bids project found that natural ventilation or mixed-mode conditioning could achieve $0.8-1.3 \%$ savings on health costs, $3-18 \%$ productivity gains, and 47 - 79\% in HVAC energy savings (World Green Building Council, 2004). In another study, Bekö (2008) suggests that financial benefits resulting from improved occupant health and productivity from more efficient air filter upgrades, may exceed the incremental costs of the new filters by a factor of twenty. In fact, the cost of SBS was point out earlier by WHO in their influential 1986 report (WHO, 1986) in which they stated, 'energy-efficient but sick buildings often cost society far more than it gains by energy savings', they further added, 'The added cost to society of the increased sensory irritation, the increased discomfort and the fear of more serious, persistent health effects among the occupants is likely to exceed any of the gains that can be made on the margins of energy savings'.

Lowering the productivity rates of occupants' performances is a crucial adverse effect of SBS. This is particularly relevant to those occupants who are continuously exposed to sick environments (i.e. employees or pupils) (Fisk, 2011; Lan, et al., 2011; Norbäck, 2009; Wargocki, et al., 2000). The predominant exposure of SBSs can potentially compel the occupants to have lower performance compared to their usual productivity (Lan, et al., 2011; Runeson-Broberg and Norbäck, 2013; Tsai, et al., 2012; Wargocki, et al., 2000; Clements-Croome, 2018) and schools (Saijo, et al., 2010; Zhang, et al., 2011; Zhang, et al., 2011).

Sick buildings can affect occupants' performances through different ways. Decreasing the quality of indoor environments is one of the key issues contributing to discomfort conditions of occupants. In a study, Singh, et al. (2010) investigated the effects of improved IEQ on perceived health and productivity in occupants in office buildings. The results demonstrated that improved IEQ contributed to the reductions of absenteeism and work hours affected by asthma, respiratory allergies, depression, and stress and to self-reported improvements in productivity. They also mentioned that green buildings may positively be considered as an effective strategy for enhancing the public health. In this line, Baird et al (2012) compared the performance of sustainable buildings versus conventional buildings from users' viewpoint. Their analysis concluded that sustainable buildings not only provide generally higher level of operation but as well, they result in an increased level of users' satisfaction.

In another study, Ahmadi, et al. (2015) investigated the effect of SBS on the productivity of 105 staff working in an office building through distribution of questionnaire survey. The findings showed that the mental SBS symptoms such as irritability, depression, mental fatigue can have a negative impact on productivity. Similarly, findings of Lan, et al. (2011)'s investigation confirmed the negative effects of SBS symptoms on people's productivity rates. They studied the impacts of thermal discomfort on health and occupants' performance in an office to elucidate the physiological mechanisms involved. The results revealed that productivity of performing tasks decreased once residents detected signs of SBS (high temperature). Also, Wargorcki et al (2006) argued that staff performance in office environments is highly correlated with indoor temperature levels. On the other hand, Karakolis and Callaghan (2014) examined the recent studies focusing on the influence of sit-stand office workstations. Among the existing 14 studies, they identified that six of these studies show lower level of discomfort upon use of sit-stand office workstations while eight studies presented an increase in staff productivity. Also, Etemadinezhad, et al (2017) explored the existence of SBS and its impacts on bank staff in Iran and their findings indicated that the satisfaction level of staff is significantly correlated with the prevalence of SBS.

Apart from the IAQ and thermal concerns, improper properties of buildings envelope, such as wall can be also counted as a factor causing discomfort for occupants. Mak and Lui (2011) reported the results of a questionnaire survey conducted to investigate the impacts of sound on office productivity and assessing the relationship between changes in office productivity and noise sources. They also studied the effects of five environmental and office design factors, namely temperature, air quality, office layout, sound and lighting on people's productivities. The outcomes yielded that among the factors examined, sound and temperature were the principal factors affecting office productivity. In another effort, De Been and Beijer (2014) studied the effects of office types on satisfaction with the office environment and productivity support in Netherlands. They surveyed the contribution of three types of office buildings, individual and shared room offices, Combi offices and flex offices, on employees' productivities. The results demonstrated the significance of office types on productivities of employees, as people felt more comfortable to be working in the individual and shared room offices. In another study, Shan, et al. (2016) studied the effects of utilizing mixing and displacement ventilation on human subjects' thermal comfort, SBS, and short-term performance. The experimental 
results indicated that higher $\mathrm{CO}_{2}$ concentration contributed to causing SBS related to head, while both higher $\mathrm{CO}_{2}$ concentration and lower relative humidity $(\mathrm{RH})$ associated to SBS related to eyes. Consequently, they concluded that SBS resulted from high $\mathrm{CO}_{2}$ concentration and low $\mathrm{RH}$ could lead to decrease in short-term performance. Furthermore, according to a study in the UK, over $80 \%$ of office staff express being in an indoor space with high temperature does now allow them to easily concentrate; approximately $60 \%$ believe in such hot indoor environment, they need $25 \%$ more time to complete their given tasks and lastly, $78 \%$ think their office environment partially kills their creativity for completing their job (USDAW, 2006).

In summary, SBS can negatively affect occupants' performances and productivity due to a number of factors, which can be conclusively summarized as the unsatisfactory IAQ; the existence of unacceptable level of humidity, $\mathrm{CO}_{2}$, and temperature in indoor environment; building layout; sound and lighting status. However, the list of factors leading to undermining the occupants' productivity can be further expanded to include more determinants such as psychological or social parameters. Figure 1 provides a comprehensive summary of the factors that contributes to SBS and their negative effects on occupants as per the reviewed studies.

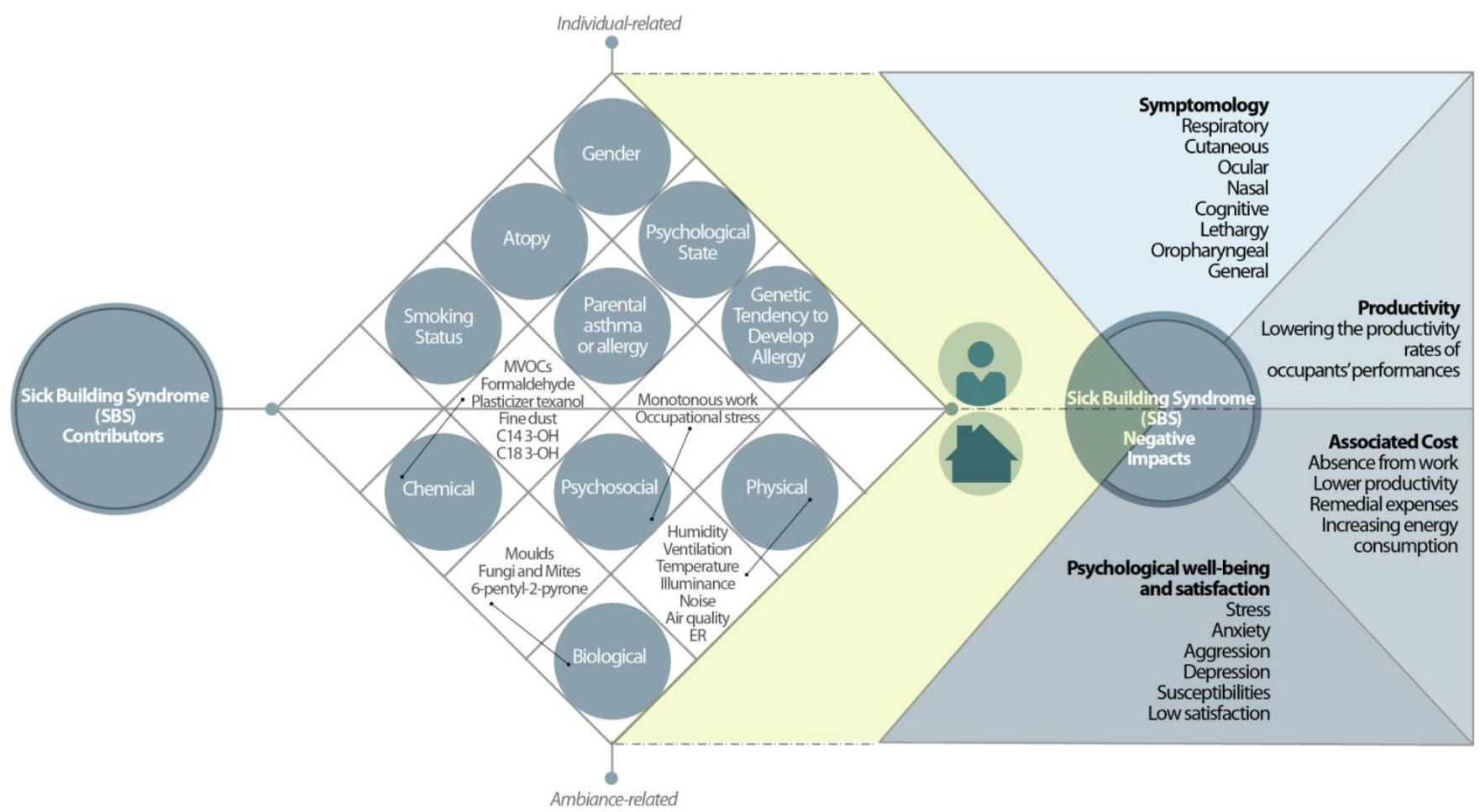

Respiratory: Allergic Rhinitis - Sinus congestion - Influenza like symptoms - Dry Cough - Throat irritation -Wheezing - Shortness of breath - Dry mucus membranes - Hoarseness of the voiceSensitivity to odors - Asthma-Cutaneous: Skin rashes - Itchy skin-Dry skin - Erythema - Lip irritation and dryness - Seborrheic dermatitis - Periorbital eczema - Rosacca - Uritcaria - Itching folliculitis - Ocular: Eye dryness - Eyes itching - Eyeswatering - Gritty eyes - Eye Burning - Visual disturbances - Light sensitivity - Swollen eyelids - Nasal: Runny nose - Sneezing - Blocked nose- Nose bleeding - Cognitive: Functional headache-Migraine headache-Tension headache-Sinus headache-Mental confusion - Lethargy: Lethargy - Difficulty in concentrating - Mental fatigueGeneral fatigue - Drowsy - Oropharyngeal: Throat dryness - Throat irritation - General: Nausea - Dizziness - Hypersensitivity reactions - Deteriorating the pre-existing illnesses

Figure 1. An overview of SBS contributors and their negative impact on occupants

\section{Review of studies mitigating SBS}

This section reviews recent studies conducted with the aim of addressing issues germane to SBS. The outcome of this section helps developing practical guidelines through discussing the recent strategies examined in the literature.

In order to address the issues related to SBS, improvement of ventilation systems has been a key strategy (Amin, et al., 2015; Lim, et al., 2015; Norbäck, et al., 2016; Shan, et al., 2016). In an effort, Shan, et al. (2016) suggested that proper design of ventilation system, besides efficient room layout including thoughtful arrangement of seating can be helpful to defuse the symptoms of SBS in tutorial rooms. These proposed strategies could be promising in facilitating the air circulation throughout the building layout and result in enhancement of IAQ. These measures can be further coupled by application of frequent cleaning and improvement of indoor hygiene status, as recommended by Norbäck, 
et al. (2016) and Zhang, et al. (2011) to bolster the efficiency of preventative measures to tackle SBS. However, mere reliance upon employment of active ventilation systems for increasing the IAQ may associate with the increase of building energy usage. This can further trigger the emergence of new concerns, namely environmental issues. As such, there is a demand from professional engineers for application of an optimized ventilation system which can maintain the internal air temperature at a comfortable range, while meeting the concerns toward energy consumption and environmental issues. Jaber and Ezzat (2017) proposed a model of Energy Recovery with Exhaust air Evaporative Cooling (EREEC) in ventilation to theoretically and experimentally test the thermal performance in Mediterranean climate. The experimental results indicated a superior saving due to the application of EREEC. The inlet temperature was reduced by $2.2^{\circ} \mathrm{C}$ at ambient temperature of $24.4{ }^{\circ} \mathrm{C}$ and by $7.5^{\circ} \mathrm{C}$ at highest ambient temperature of $35.7{ }^{\circ} \mathrm{C}$. Additionally, simulation results showed that the base cooling load can be reduced up to $13.38 \%$. Moreover, the payback period of EREEC from annual energy saving occurred is around 8 years.

Lim, et al. (2015) explored using a thermostat in the air-conditioning system in order to control room temperature, plus performing frequent house cleaning to reduce house dust mites allergens in the tropical office environments. The use of thermostat enables the ventilation system to be activated once the indoor temperature reaches a certain point. Therefore, it avoids the ventilation system to be constantly operational and result in saving up energy. In another study, Amin, et al. (2015) stated that poor application of ventilation system may lead to SBS symptoms and affect students' health. As a result, they recommended the use of proper functioning control system to maintain a comfortable indoor environment for occupants.

$\mathrm{Lu}$, et al. (2016) expressed that reduction of household mold/dampness, control air pollution emissions from home renovations, and improving building ventilation through frequent opening windows and use of an exhaust fan in bathroom can be efficacious in order to deal with SBS symptoms. Additionally, Norbäck and Nordström (2008) explored a number of strategies to deal with SBS, namely careful control of classrooms' temperature through air conditioning, utilization of sun shield to control the incoming sun radiations and use of sufficiently high ventilation flow in the classrooms. Furthermore, application of ventilation was also introduced as an effective measure to control indoor air pollution caused by Volatile Organic Compound (VOCs) emissions (Kim, et al., 2008). Takigawa, et al. (2009) also introduced the existence of chemicals (i.e. indoor aldehydes, VOCs, airborne fungi, and dust mite allergens) as the major contributors to SBS. They suggested the consideration of preventive strategy designed to mitigate the exposure to indoor chemicals as a solution to counter the occurrence of SBS in newly built houses. Minimizing the interior building products to exterior, decrease the moisture accumulation during construction and striking the balance HVAC systems to control thermal comfort and humidity were among the recommendations given by Crook and Burton (2010) to reduce the possibility for indoor development of mold. Assimakopoulos and Helmis (2004) also found the existence of SBS symptoms among the employees working at the air traffic control tower in Athens. They suggested a number of measures to eliminate the symptoms and improve the poor IAQ, in which was identified as the principle contributor in occurring SBS. i) restriction of smoking in indoor spaces, ii) checking all HVAC systems, replacement of the air filters and cleaning all screens of the outdoor air intakes of the systems, iii) cleaning, checking and regulating inlet and outlet openings (diffusers) of the HVAC systems inside the various rooms of building to deliver maximum air supply iv) cleaning the plenum, floor, carpet and all equipment and furniture, v) opening the building's windows and doors to supplement the room ventilation, vi) cleaning the outdoor areas around the building, which are close to the air intakes of the HVAC systems. Notwithstanding the promising results achieved to improve the occupants' well beings, these conducted studies paid no or considerably limited attention to the energy performance of buildings. Building sector has already performed a considerable role in consuming a large portion of global energy (Omrany, et al., 2016), therefore, from a critical perspective, the demand for enhancement of occupants' wellbeing should be addressed by exploring strategies that not only lead to the development of healthy environments for the occupants but also consider the concerns toward global energy crisis. As reviewed earlier, WHO (1986) pointed out that SBS is likely to cost the society more than the saving that could be achieved by applying energy-effect measures in buildings. This includes not only the monetary value but also people's confidence on the effectiveness of health and building authorities.

Apart from the reviewed strategies, several studies have been carried out to assist the improvement of IAQ and addressing SBS concerns. One of these measures is the use of green building for enhancing the health status of occupants (MacNaughton, et al., 2016; Paul and Taylor, 2008; Thatcher and Milner, 2016). To answer the question whether green building can have a really better impact on occupants, Thatcher and Milner (2016) conducted a longitudinal study to empirically investigate three green buildings through using a pre-test, post-test design, and repeated measures design with a contrast group for two of the buildings. The statistical analyses established significant 
improvements in perceived air quality across all three buildings, significant improvements in self-report productivity in two of the buildings and a significant improvement in physical wellbeing in one building. In another study, MacNaughton, et al. (2016) investigated the influence of green building on improving the health status through recording and monitoring the IEQ, self-reported health, and heart rates of participants dwelling in two green and conventional buildings. The findings indicated that participants consistently reported fewer symptoms during the green building conditions. It is also claimed that green buildings can have a direct impact on decision-making process of residents. MacNaughton, et al. (2017) conducted a cognitive function test among 109 participants from ten high performing buildings (i.e. buildings surpassing the ASHRAE Standard 62.1-2010 ventilation requirement and with low total volatile organic compound concentrations) in five U.S. cities. The findings revealed that workers in green certified buildings scored $26.4 \%$ higher on cognitive function tests, controlling for annual earnings, job category and level of schooling, and had $30 \%$ fewer sick building symptoms than those in non-certified buildings. Although it is still arguable that the utilization of green building may not necessarily guarantee the deliverance of desirable IAQ (Steinemann, et al., 2016), but with the reference to the promising performance of green buildings in saving energy (Foustalieraki, et al., 2017; Pérez, et al., 2017), and the results indicating promising achievements in enhancement of IAQ and occupants' well beings, further exploration of green buildings deems practical and operative.

From another side, Ghashghaei et al. (2017) examined the impacts of cool colours in indoor environments on the sensation of elderlies in high-rise condominiums in Malaysia. They realized that cool colours can significantly alter the levels of blood pressure, heart beat rate and skin temperature. Their analysis concluded that use of particular cool colours can result in relaxation feeling. Moving on, from a psychological point of view, a visual and/or physical access to nature is likely to improve people's wellbeing in buildings. While this notion has been around since at least 1976 (Ludlow, 1976), it is recently known as Biophilic design (Cramer and Browning, 2008). The term Biophilia might be first used in this context by the socio-biologist Edward Wilson to describe his connection to nature (Wilson, 1984). It was later assumed that humankind's connection to nature is innate and hence our physiological responses to experiencing being in nature is genetically programed (Kellert and Wilson, 1993). This hypothesis has been widely tested at different levels and in different contexts. Evidences that support the positive impact of nature on people's physiological wellbeing are not scarce (Kellert, 2012) and scientifically tested (Ryan et. al., 2014). Examples include improved mental health (Ulrich, 1979; Tyrväinen et al., 2014), reduced stress (Berman et al., 2008; Matsunaga et al., 2011), increased well-being (Ulrich et al., 1991; Ikei et al., 2014), attention restoration (Kaplan, 1995; Raanaas et al. 2011) and faster healing rates (Ulrich, 1984; Park and Mattson, 2008).Providing a window with a view to a pleasing nature scene or indoor planning allows the eye to adjust and re-focus, which reduces fatigue, headaches resulting in better health, less frustration, and better overall performance in work places (Kaplan, 1992; Van, 2001). In the healthcare sector, a recent substantial report found that providing patients with views of nature could save the US healthcare authorities up to $\$ 93$ million/year (Browning, 2012). In fact, research has shown a reasonable awareness of the importance of providing view to nature in hospital among designers. For example, Alalouch, et al. (2015) conducted a Conjoint Analysis study to explore priorities of a group of UK-based architect's when designing a hospital; and found that "creating a view to outside" lies at their top priority when design a hospital ward. Nevertheless, views to nature could be provided by creating atriums, courtyards, communal sky gardens with real trees and plants, or roof gardens (World Green Building Council, 2004). On the other hand, Largo-Wight et al (2011) presented that in working environments, there is a significant negative correlation between nature contact and stress as well as nature contact and health-related complaints. More recently, another study indicated that in office spaces that are exposed to natural daylight and vegetation, staff are 15\% more creative and 6\% more productive (Human spaces report, 2015). Biophilic design is not limited to providing visual/physical access to nature. Söderlund and Newman (2017) categorized the key elements of biophilic design into three categories based on the works of Cramer and Browning (2008) and Ryan, et al (2014).

1) 'Nature in the space'; incorporating plants, water, animals and movement into the built environment.

2) 'Natural analogues'; suggesting patterns/materials that evoke the nature.

3) 'Nature of the space'; referring to different spatial configurations and associated physiological/psychological responses they engender such as prospect, refuge, mystery and risk/peril.

These studies (Cramer and Browning, 2008; Ryan et. al. 2014) support the proposition that biophilic design is likely to mitigate the effect of SBS, improve the overall wellbeing of the occupants, and contribute positively to their satisfactions, productivity and performances.

In conclusion, a number of strategies and methodologies are put forward and suggested in the relative literature in order to tackle the issues concerned with SBS. Table 5 provides a comprehensive summary of these strategies, whereas Figure 2 separates these strategies according to their effectiveness and ease of implementation in existing/future buildings as assessed in literature. It generally compares the less complex approaches (H1 \& H3) from effectiveness 
viewpoint and demonstrates that mitigations (H3) such as use of non-toxic materials and openable windows or biophilic design embrace greater potentials. On the other hand, it compares complex mitigations (H2 \& H4) and postulates that approaches (H4) such as full reduction of mold and use of advanced ventilation systems as well as advanced air quality controls, passive design techniques and smart building skins are relatively more effective. Thus, it presents how proposed mitigations can be complex but not adequately effective or how less complex approaches can have significant influence while presenting selected complex mitigations with promising results (section 5 further elaborates on this discussion).

Table 5. Strategies to tackle the SBS

\begin{tabular}{|c|c|c|}
\hline Author (s) & Proposed Strategy to tackle SBS & Building type \\
\hline (Shan, et al., 2016) & $\begin{array}{l}\text { Proper design of ventilation system and careful } \\
\text { arrangement of room layout }\end{array}$ & University \\
\hline (Norbäck, et al., 2016) & Improvement of cleaning in schools & Schools \\
\hline (Lim, et al., 2015) & $\begin{array}{l}\text { Improvement of ventilation system, and frequent } \\
\text { cleaning }\end{array}$ & $\begin{array}{l}\text { Office environment, } \\
\text { University }\end{array}$ \\
\hline (Amin, et al., 2015) & $\begin{array}{l}\text { Use of functioning control system to control the } \\
\text { indoor air temperature }\end{array}$ & Laboratory \\
\hline (Lu, et al., 2016) & $\begin{array}{l}\text { Reduction of mold/dampness, control air pollution } \\
\text { emissions from home renovations, and enhancement } \\
\text { of building ventilation }\end{array}$ & Home \\
\hline (Norbäck and Nordström, 2008) & $\begin{array}{l}\text { Regulation of indoor temperature, Sun shield, use of } \\
\text { sufficient ventilation system }\end{array}$ & Classroom \\
\hline (Zhang, et al., 2011) & Frequent cleaning and improving hygiene & School \\
\hline $\begin{array}{l}\text { (MacNaughton, et al., 2016; } \\
\text { MacNaughton, et al., 2017; Singh, } \\
\text { et al., 2010; Miller, et al., 2009; } \\
\text { Thatcher and Milner, 2016) }\end{array}$ & Green building & $\begin{array}{l}\text { Office building, } \\
\text { Residential building }\end{array}$ \\
\hline $\begin{array}{l}\text { (Kaplan, 1992; Van and Bergs, } \\
\text { 2001; Söderlund and Newman, } \\
\text { 2017; Ghashghaei, et al, 2017) }\end{array}$ & $\begin{array}{l}\text { Biophilic design (view/access to nature); indoor } \\
\text { plants; nature patterns, colors, and materials; spatial } \\
\text { configurations that are provided by nature. }\end{array}$ & $\begin{array}{l}\text { Prison building, } \\
\text { Elderly house, } \\
\text { Office building }\end{array}$ \\
\hline
\end{tabular}

Accordingly, the most prevalent measure claimed to address the SBS symptoms is associated with application of proper ventilation systems in buildings. These reviewed strategies can be generally classified into two major groups; first group refers to those measures that do not require major considerations such as physical modification in buildings structure in order to rectify the SBS symptoms such as frequent cleaning procedures or maintaining the hygiene in buildings. Second group refers to those measures that require considering the physical alterations such as usage of greeneries in building or improvement of mechanical ventilation systems. Apart from these measures, it is believed that SBS can be categorized as a pollution-related illness (Imai and Imai, 2011). Therefore, national governments must also attempt to solve these problems by making building regulations that prevent the use of toxic materials in living environments and/or providing financial support for SBS patients to take radical measures to solve their problems. Yet, there is a dearth of attempts performed to address the SBS related issues with consideration of all potential strategies altogether. 


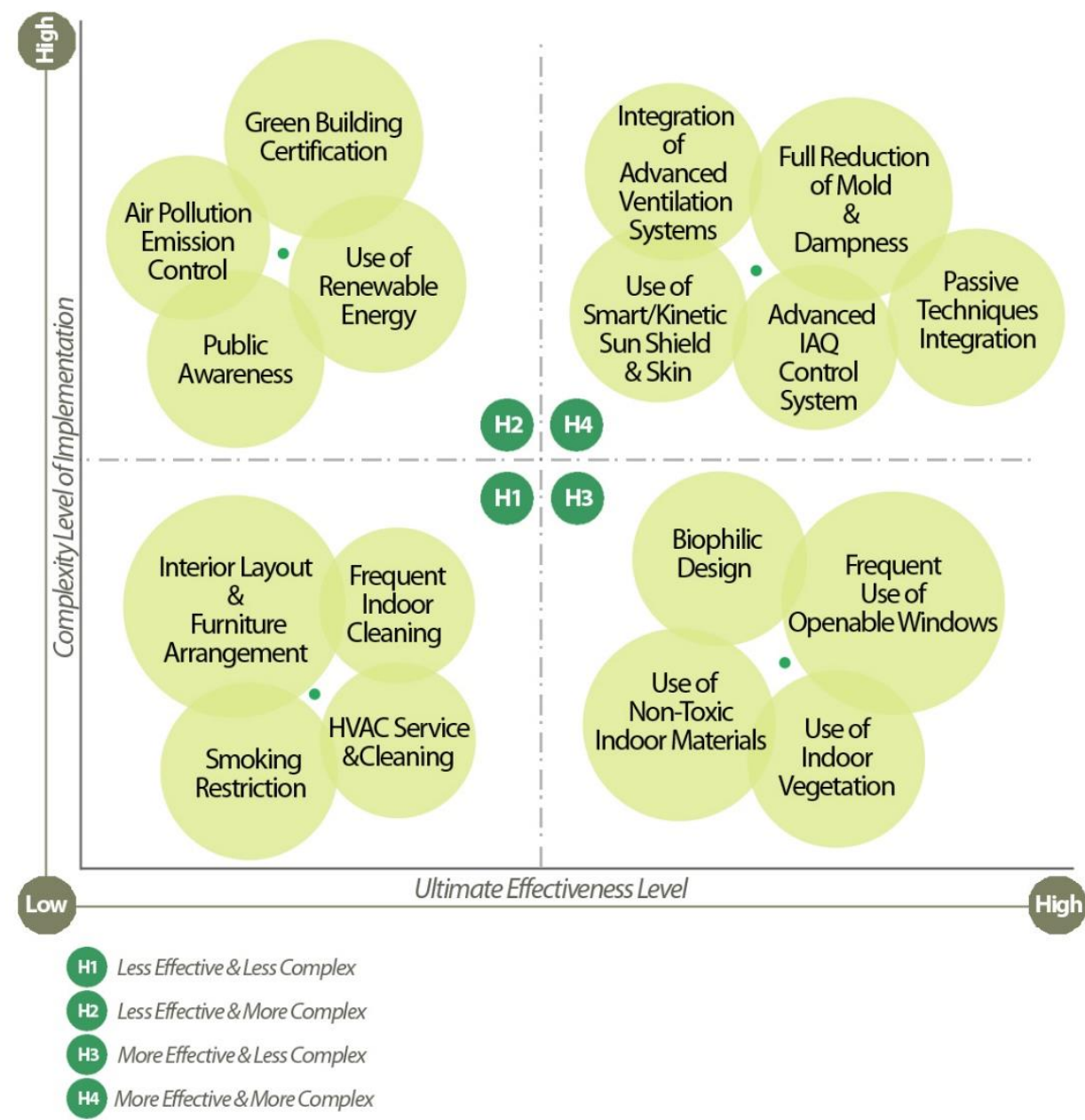

Figure 2. The matrix for SBS mitigation through an evaluation of the complexity and effectiveness of mitigation strategies as part of healthy built environments

Based on the review of recent studies (Abdul-Wahab, 2011; Vural and Balanl1, 2011; Clements-Croome, 2018), it can be deduced that in order to effectively tackle SBS and achieve a healthy indoor environment, the following key attributes should be taken into account:

- Fresh and clean air and proper (natural) ventilation while maintaining indoor air quality (i.e. cross ventilation provides the most ventilation)

- $\quad$ Thermally comfortable environment (i.e. acceptable level of temperature, humidity, PMV)

- Adequate acoustic level and minimized level of external noise

- Acceptable level of $\mathrm{CO}_{2}$ and minimized level of indoor pollutants (i.e. $\mathrm{NO}_{2}$ )

- Control moisture levels (i.e. too much moisture can increase growth of bacteria, and mould)

- Sufficient daylight and no glare (i.e. window sizes should be carefully considered and be fit for purpose)

- Solar gain control (i.e. Too much glass can lead to internal overheating).

- Acceptable material usage with no issues of toxicity, microbe, dampness, mold, and similar challenges

- External views, and determines the window height required for views

- Appropriate landscape allocation and possibly nature contact

- Proper colour use relevant to the function of spaces

- Proper segregation of spaces for sense of privacy once required

- Efficient plan layout and furniture arrangement to promote flexibility and collaboration 
- Ergonomic indoor layout

Adequate use of digital technology once requiredNote: Taking all of the above considerations into account in professional practice may be complex and multifaceted.

\section{Future Directions of Buildings from SBS Perspective}

Well-being, embracing health and comfort, is a critical parameter for determining the quality of life of an occupant. In late 1980s and during the 1990s, WHO concept of health, became significant for identifying the concept of a 'healthy building' in terms of building performances (i.e., IAQ, thermal comfort, lighting quality and acoustics) (Bluyssen, 2010). A healthy building is defined as 'built environment that encourages positive well-being of human beings' (Ho, et al., 2004; Mohtashami, et al., 2016). Moreover, a broader definition is proposed by Levin (1995), considering the impacts of buildings on both occupants and surrounding environments. Levin defined healthy building as 'a building that adversely affects neither the health of its occupants nor the larger environment'. From a more generic outlook, a healthy building is free of hazardous materials (e.g. lead and asbestos) and capable of fostering health and comfort of the occupants during its entire building life cycle, while supporting social needs and enhancing productivity. While Levin aspiration calls for 'treads lightly on the earth', this brings in other dimensions- such as the total amounts of materials used in the construction and operation of a building and the environmental impact of the mining/production/transportation to site and subsequent disposal of waste. In short, this would require lifecycle analysis of the wider environmental impact of buildings. This reveals the 'health' and 'well-being' approaches as being flawed because they are entirely species-centric and lacking regard for other flora and fauna.

This study critically argues that there is a gradual shift from the current predominant focus on 'sustainable and intelligent design' to 'healthy design' as a fundamental basis of future buildings. Figure 3 forms a conceptual framework for healthy buildings based on physical, perceptual and economic dimensions through touching on the subjective and objective health-related parameters. It should be stressed that while there has been a growing attention towards taking objective healthy design principles into consideration (i.e air quality, noise, daylight, etc), there has been a relatively limited focus on subjective aspects such as attributes related to views, nature, or building character. On the other hand, for maximizing the impacts of healthy design, more attention should be drawn to the perception of occupants with regards to their sense of happiness, security or well-being. Lastly, the relationship between healthy design principles and cost-related factors is of significant importance from the viewpoint of occupants, landlords, developers and governmental sectors. This healthy design vision should not only be observed at building-scale level as its urban and city-scale image allows effectively contributing to the eventual goals of smart and intelligent cities. Hence, the analysis expresses that the main problem is larger than the buildings-related SBS challenges. Thus, a working hypothesis is that the broader environmental conditions should be initially fixed up before being capable of entirely solving the building problems. This brings more attention to the broad drivers of SBS including climate change, rapid urbanisation, external environmental quality, and occupants being more isolated from natural environments.

Do current standards go far enough? A healthy building recognizes the human health needs, and responds to the occupants' comfort requirement as the top priority. But beside these tangible benefits, there is a need to consistently draw attention to its potentials for intangible output ranging from stress reduction to mental calmness and happiness. Likewise, a healthy building should be ready and capable to respond to future needs, adaptable to 'new drivers' such as climate change, and responsive to the changes towards a multifunctional and diverse society, the increasing individualization and the ever-changing needs and preferences of occupants (See Figure 4). 


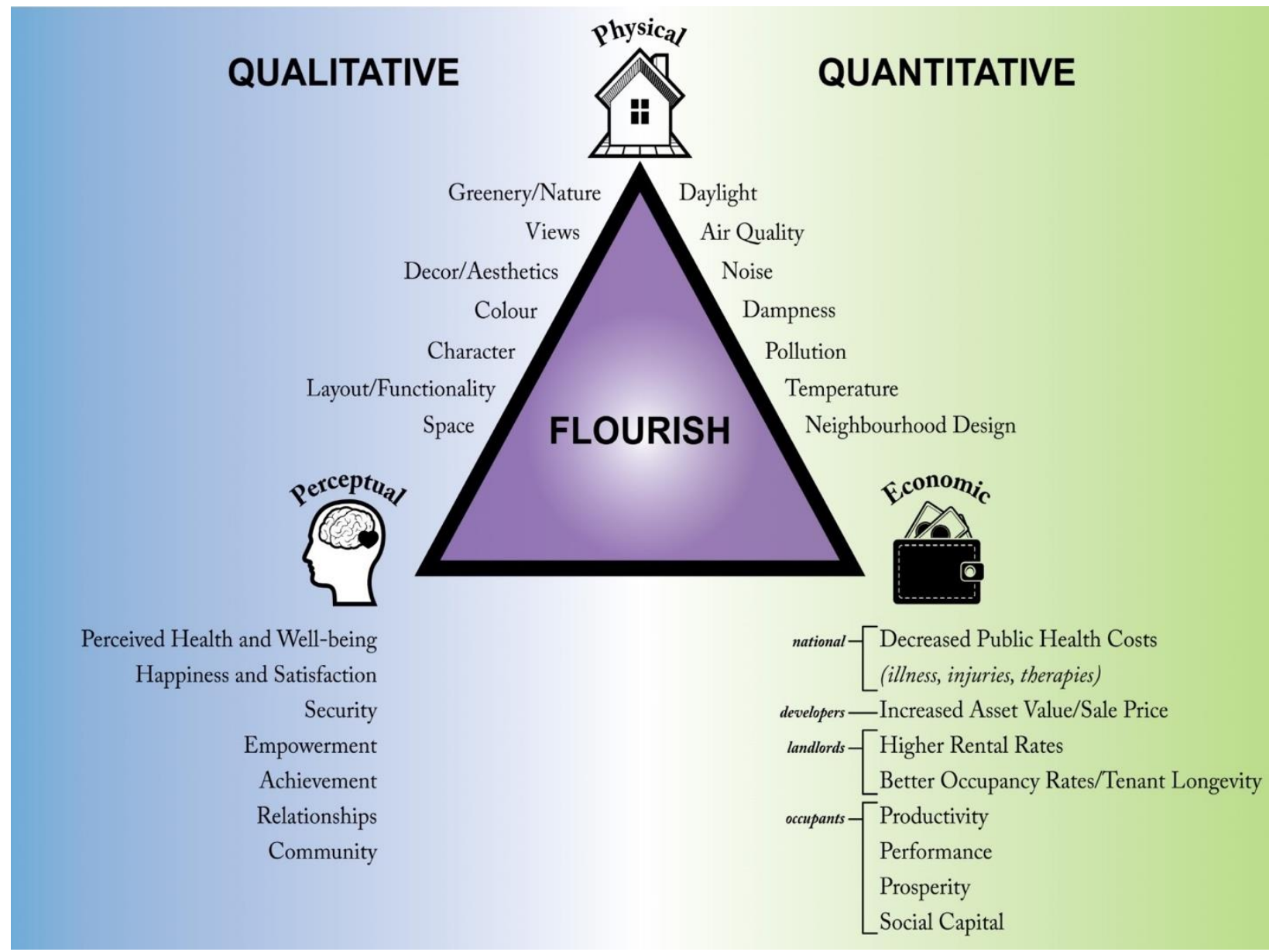

Figure 3. Flourish Model for healthy buildings, source: Clements-Croome 2018

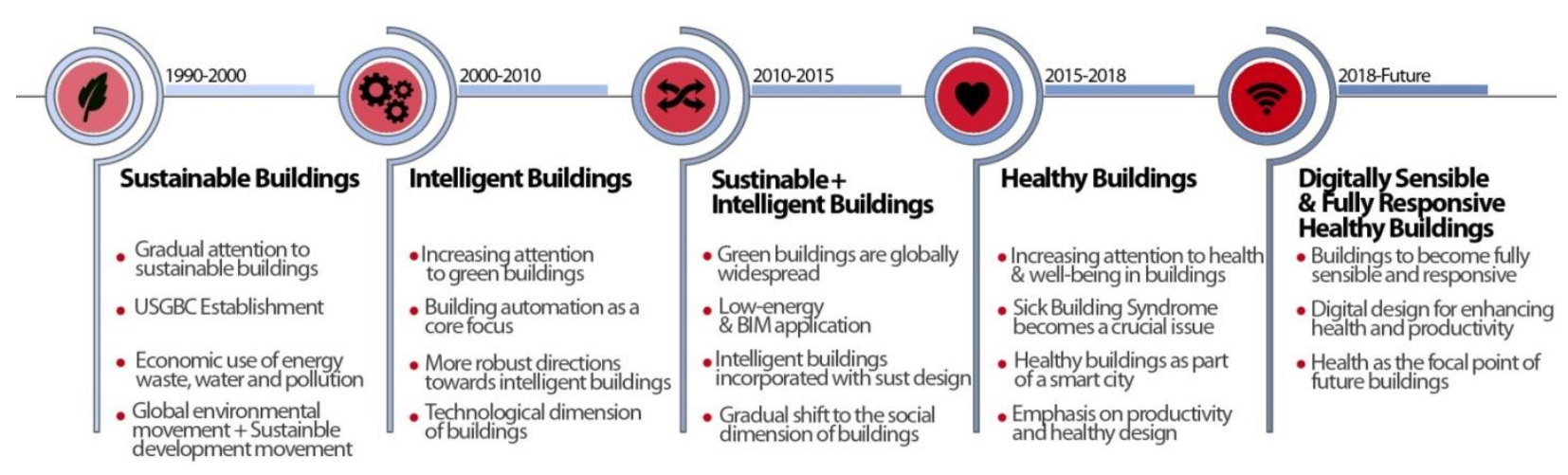

Figure 4. The role of SBS: Evolution of building design and development from sustainable, intelligent and healthy design perspectives

In principle, healthy buildings should be developed based on successful fulfilment of various technical requirements such as being in line with proper design and construction principles of buildings and their satisfactory performance with view to providing sufficient IAQ, visual comfort, daylight and natural ventilation without compromising the occupants' health and satisfaction (Loftness, et al., 2007; Heidari, et al, 2017; Clements-Croome, 2018). However, 
Rees (1999) would argue that this focus solely on occupants (building end users) - and not on 'distant elsewhere' is a continual failing of the design and construction industries which 'draw on resources and dump their garbage all over the world'. This ecological reality underscores the urgency of 'healthier factors' in the building industry.

Overall, the result of reviewed studies reveals the significant impact of buildings' health-related parameters not only on occupants but in many different ways, take into account the health and well-being of those involved in producing the materials or constructing buildings or servicing their operation. This can be deemed as a convincing reason to justify more rigorous consideration of both objective and subjective healthy principles during the design, construction and operational phases of buildings towards tackling SBS. The following paragraphs discuss the major principles to be taken into account towards future healthy buildings. Likewise, Table 6 sums up the overview of SBS contributors and selected mitigation approaches, as part of a healthy building, from complexity, duration and cost point of views.

Table 6. Overview of SBS contributors and mitigations approaches from complexity level, duration and cost viewpoints

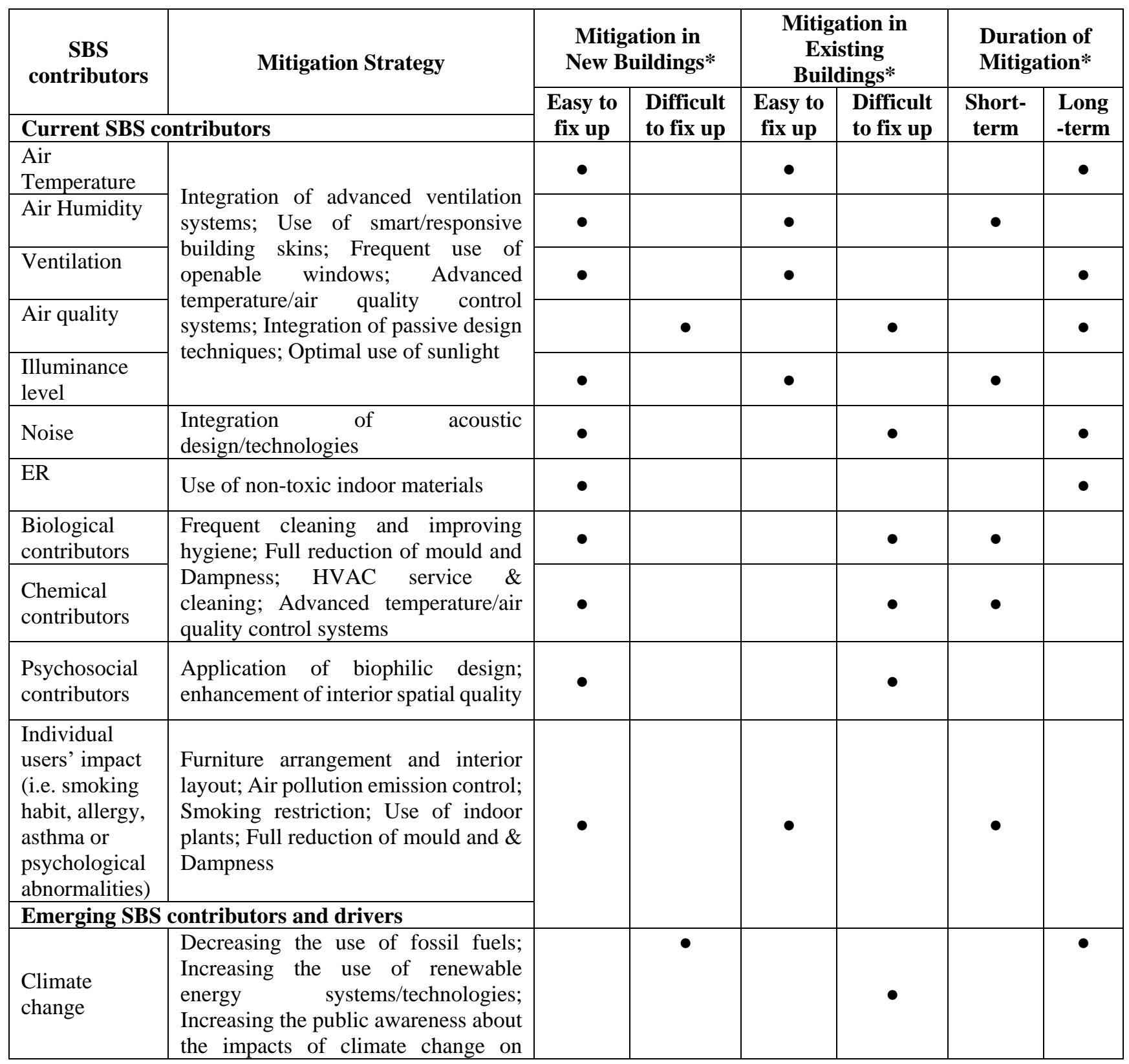




\begin{tabular}{|c|c|c|c|c|}
\hline & $\begin{array}{l}\text { human health; Launching global and } \\
\text { national-wide incentives and policy- } \\
\text { based schemes to control climate } \\
\text { change }\end{array}$ & & & \\
\hline $\begin{array}{l}\text { Rapid } \\
\text { Urbanisation }\end{array}$ & $\begin{array}{l}\text { Context-aware urban planning and } \\
\text { spatial infrastructure design; } \\
\text { promotion of liveable cities; } \\
\text { government } \\
\text { incentives/policies/regulations for } \\
\text { low-carbon design and urban } \\
\text { resilience; Increasing the public } \\
\text { awareness about the impacts of rapid } \\
\text { urbanization on human health }\end{array}$ & $\bullet$ & $\bullet$ & $\bullet$ \\
\hline $\begin{array}{l}\text { Occupants' } \\
\text { behaviours }\end{array}$ & Increasing public awareness & $\bullet$ & $\bullet$ & $\bullet$ \\
\hline \multicolumn{5}{|c|}{$\begin{array}{l}\text { * Clarifications for the utilized terms: } \\
\text { Easy to fix up: Requires less complex design/technological implementations } \\
\text { Difficult to fix up: Requires complex design/technological implementations } \\
\text { Short-term: Requires limited duration of design/technological implementation ( }<6 \text { months }) \\
\text { Long-term: Requires extensive duration of design/technological implementation }(>6 \text { months })\end{array}$} \\
\hline
\end{tabular}

\section{Conclusions}

The exposure of occupants to unhealthy indoor environments can potentially trigger the emergence of SBS symptoms. This paper attempted to advocate the crucial role of healthy buildings, based on their significant impacts on occupants' health and well-being, through exploring the negative effects of sick buildings. The review critically showed that sick buildings are likely to endanger the occupants' health status while negatively affecting the level of productivity. On the contrary, the concept of healthy building has been discussed through highlighting its major promising principles including the maintenance of IAQ and thermal control, maximizing the use of daylight, providing a workplace in compliance with the occupants' ergonomics and creating opportunities for occupants to access nature. Additionally, this study redefines the concept of healthy building through including the importance of energy management in its scope, besides its capability to procure flourishing environments and assuring the occupants' health (ClementsCroome 2018).

This study has identified physical, biological, chemical, psychosocial and individual parameters as the major contributors to SBS. These factors facilitate the emergence of SBS symptoms, in which they result in bringing several negative effects for occupants. The analysis categorized these effects into four major groups. The first one is the symptomatology that refers to nasal, ocular, oropharyngeal, cutaneous and general manifestations. The second one is the psychological effect of SBS such as stress and anxiety; as well as the impact of SBS on occupants' satisfaction. The third effect refers to the costs associated with occurrence of SBS such as the absence from work, lower productivity, remedial expenses, or increasing the building energy consumption. The fourth effect refers to compromising the productivity of occupants in sick buildings. Although the reviewed points cover majority of negative effects attributed to the SBS, but these effects can go beyond that, namely social effects of SBS. Therefore, future studies will be required to address new aspects of SBS.

Reviewing recent studies has revealed that the physical features of buildings can be influential in appearing SBS symptoms. The adverse effects of physical contributors on occupants' health during the operational phase of building can be initially neutralized through practicing a careful architecture during the building's design phase. It can be stated that the accurate consideration of building's orientation, felicitous selection of building materials in accordance with local climate, application of passive techniques in building envelope such as passive walls can be efficacious in avoidance of occurring the physical contributors. These design principles may potentially facilitate the air circulation throughout the building, manage recipient of a sufficient amount of solar radiations and providing a required measure of illuminance for occupants. The control of physical contributors can be further promising in minimization of biological and psychosocial contributors.

It should be stressed that healthy buildings are beyond SBS and embrace many other interrelated aspects such as stress, physical mental, musculoskeletal impacts, social well-being and others health-related attributes (Clements-Croome, 
2018). Indeed, healthy building is a better conceptualization than what we have today but requires consistent in-depth exploration to unleash new potentials. This study identifies a number of strategies to improve the issues concerned with SBS namely; proper design of ventilation systems, careful arrangement of room layouts, sanitizing frequency, reduction of mold/dampness, installation of external devices on openings such as sun shades, development of green buildings and providing visual/physical access to nature. Despite the stand-alone influences of the abovementioned factors, further investigations to address their interrelated effects are essential. Lastly, from the professional practice perspective, while the main focus of this research was on the identification of SBS indicators and their impacts, highlighting the current needs to pave the way for healthier buildings, it is vital to continue this debate regarding the role of professionals and professionalism in this context. Without a doubt, more in-depth explorations should be carried out to dictate the role of architects, engineers, and building technology experts towards creating healthier indoor environments.

Building for health and wellbeing is presented in this paper as a moving target where there is neither a 'state to be reached' nor a 'one-size-fits-all' solution. This implies creating a secure sense of long term vitality, with sustainable thinking influencing all aspects of development, from the built form to financial, technological, economic and social policies and delivery mechanism. Healthy/ well-being approach does not happen as an outcome in a 'predetermined way'. It requires to be carefully discussed, openly debated and even centrally planned. The concept will need to be translated into real and tangible design solutions if the built environments are to avoid serious problems and costs in the future (Trained, 2011). This may move the design for health and well-being debate away from 'best practice' and towards 'next practice', focusing on innovation in the design of housing, workplaces, schools, public spaces and transport (Trained, 2011).

Meeting the objectives and apprehensions described above confront professional bodies and individuals with a major challenge on how to become more responsible for healthier places. Unlike the deterministic conventional physical-led approach to green/sustainable building design, many contemporary thinkers emphasize the inter-relationship between people's lives and their environment and advocate taking a more strategic and holistic approach. Therefore, any search concerning healthier places must consider the built environment as a complex system. Thus, multi-level, multisectorial policymaking challenges along this way must be coordinately addressed to materialize desired healthier outcomes. Realizing this goal may require investigations on a 'new professionalism' which must span all across the built environment, planning, engineering and design professions based on their interconnectivity and collective responsibilities, including fully appraising desired healthier outcomes (Cooper, 2009; Hill and Lorenz, 2011). Indeed, such approach is a necessity if our health, wellbeing and quality of life are to be enhanced, and thus GHG emissions to be seriously mitigated. Roberts (2009) argued that placing emphasis on applying (subject-specific) specialist skills can result in the full or partial exclusion of wider generic competences (Roberts 2009): over dependence on discipline skills may be redressed by expanding professionals' knowledge and skills toward the social and cognitive competences required for sharing experience and insights. Achieving this would require paying detailed attention to understanding the patterns of relationships between the wish-list of desires voiced by academics in this paper in order to provide clues for understanding how effective outcomes emerge. Successful building design process would thus require explicitly managing for integration and harmonisation across disciplines and phases, as well as between and among team members and local stakeholders from a wide range of disciplines and constituencies - including the interface of private and public exchange. This would be needed to ensure the effective capture and integration of both explicit/professional and tacit/lay forms of knowledge into more deliberative forms of practice (Cooper, 2009).

To sum up, the following research-based future actions are recommended for further exploring the SBS impacts, enhancing the capacity of healthy buildings and contributing to the overall well-being and health status of inhabitants:

- To present a more holistic and inclusive definition of healthy buildings with no limit to SBS but moving beyond the current boundaries

- To expand the technical studies on the evaluation of buildings from health perspective (soft and hard issues) to demonstrate the most crucial obstacles and future direction

- To move beyond sustainable buildings and interconnect the sustainable design principles to healthy design attributes

- To similarly explore the weaknesses, challenges and drawbacks of healthy design rather than predominantly concentrating on its benefits

- To clarify the role of industry professionals for promoting healthy buildings during the implementation and application phases based on an explicit understanding of SBS impacts and other health-related parameters 
- To increase the public awareness regarding the impacts of buildings on health and well-being

- To develop incentivized programs and policies to encourage the professionals as well as building owners to move towards the proliferation of healthy buildings

- To strike an urban-scale vision towards the possible impacts and potentials of SBS versus healthy buildings at city level

- To identify the principal actors in delivering the above-suggested implementations in practice

\section{Acknowledgements}

We would like to thank Professor Richard Hyde, the editor of Architectural Science Review, for his constructive feedback and thoughtful recommendations. Also, we would like to thank Dr. Ian Cooper from Eclipse Research in the UK for his critical reviews and technical advices on the earlier versions of this paper.

\section{References}

1. Abanda, F. H., \& Byers, L. (2016). An investigation of the impact of building orientation on energy consumption in a domestic building using emerging BIM (Building Information Modelling). Energy, 97, 517-527.

2. Abdul-Wahab S. (2011). Sick Building Syndrome: in Public Buildings and Workplaces, Springer Science \& Business Media.

3. Ahmad, N., \& Hassim, M. H. (2015). Assessment of indoor air quality level and sick building syndrome according to the ages of buildings in Universiti Teknologi Malaysia. Jurnal Teknologi, 76(1).

4. Ahmadi, M., Golbabaei, F., Behzadi, M. (2015). The effect of sick building syndrome (SBS) on the productivity of administrative staff. International Journal of Occupational Hygiene, 6(4), 210-219.

5. Ahvenniemi, H., Huovila, A., Pinto-Seppä, I., \& Airaksinen, M. (2017). What are the differences between sustainable and smart cities? Cities, 60, 234-245.

6. Alalouch, C., Aspinall, P., \& Smith, H. (2015). Architects' priorities for hospital-ward design criteria: Application of choice-based conjoint analysis in architectural research. Journal of Architectural and Planning Research, 32(1), 1-22.

7. Alalouch, C., Saleh, M. S. E., \& Al-Saadi, S. (2016). Energy-Efficient House in the GCC Region. Procedia-Social and Behavioral Sciences, 216, 736-743.

8. AlWaer, H., and Illsley, B. (2017). Rethinking Masterplanning: Creating Quality Places. ICE Publisher (Institute of Civil Engineerings): London.

9. Amin, N. D. M., Akasah, Z. A., \& Razzaly, W. (2015). Architectural Evaluation of Thermal Comfort: Sick Building Syndrome Symptoms in Engineering Education Laboratories. Procedia-Social and Behavioral Sciences, 204, 19-28.

10. Annesi-Maesano, I., Hulin, M., Lavaud, F., Raherison, C., Kopferschmitt, C., de Blay, F., ... \& Denis, C. (2012). Poor air quality in classrooms related to asthma and rhinitis in primary schoolchildren of the French 6 Cities Study. Thorax, thoraxjnl-2011, 200391.

11. ASHRAE. (2007). ASHRAE Standard 62.1e2007, Ventilation for Acceptable Indoor Air Quality. Atlanta, GA, USA: ASHRAE; 2007.

12. ASHRAE. (2009). Indoor Air Quality Guide (ISBN 978-1-933742-59-5).

13. Assimakopoulos, V. D., \& Helmis, C. G. (2004). On the study of a sick building: the case of Athens Air Traffic Control Tower. Energy and Buildings, 36(1), 15-22.

14. Azzam, E. I., Jay-Gerin, J. P., \& Pain, D. (2012). Ionizing radiation-induced metabolic oxidative stress and prolonged cell injury. Cancer letters, 327(1), 48-60.

15. Bachmann, M. O., \& Myers, J. E. (1995). Influences on sick building syndrome symptoms in three buildings. Social Science \& Medicine, 40(2), 245-251.

16. Bakó-Biró, Z., Clements-Croome, D. J., Kochhar, N., Awbi, H. B., \& Williams, M. J. (2012). Ventilation rates in schools and pupils' performance. Building and Environment, 48, 215-223.

17. Barton, H. (2016). City of well-being: A radical guide to planning. Taylor \& Francis.

18. Barton, H., Grant, M., \& Guise, R. (2010). Shaping neighbourhoods: a guide for health, sustainability and vitality. Taylor \& Francis.

19. Baird, G., Leaman, A., \& Thompson, J. (2012). A comparison of the performance of sustainable buildings with conventional buildings from the point of view of the users. Architectural Science Review, 55(2), 135-144.

20. Bavarnegin, E., Fathabadi, N., Moghaddam, M. V., Farahani, M. V., Moradi, M., \& Babakhni, A. (2013). Radon exhalation rate and natural radionuclide content in building materials of high background areas of Ramsar, Iran. Journal of environmental radioactivity, 117, 36-40.

21. Bernstein, J. A., Alexis, N., Bacchus, H., Bernstein, I. L., Fritz, P., Horner, E., ... \& Reijula, K. (2008). The health effects of nonindustrial indoor air pollution. Journal of Allergy and Clinical Immunology, 121(3), 585-591.

22. Basner, M., Babisch, W., Davis, A., Brink, M., Clark, C., Janssen, S., \& Stansfeld, S. (2014). Auditory and non-auditory effects of noise on health. The Lancet, 383(9925), 1325-1332.

23. Baykara, O., Karatepe, Ş., \& Doğru, M. (2011). Assessments of natural radioactivity and radiological hazards in construction materials used in Elazig, Turkey. Radiation Measurements, 46(1), 153-158. 
24. Bekö, G., Clausen, G., \& Weschler, C. J. (2008). Is the use of particle air filtration justified? Costs and benefits of filtration with regard to health effects, building cleaning and occupant productivity. Building and Environment, 43(10), 1647-1657.

25. Bellos, E., Tzivanidis, C., Zisopoulou, E., Mitsopoulos, G., \& Antonopoulos, K. A. (2016). An innovative Trombe wall as a passive heating system for a building in Athens-A comparison with the conventional Trombe wall and the insulated wall. Energy and Buildings, 133, 754-769.

26. Berman, M. G., Jonides, J., \& Kaplan, S. (2008). The cognitive benefits of interacting with nature. Psychological Science, 19, 1207-1212.

27. Berson, D. M., Dunn, F. A., \& Takao, M. (2002). Phototransduction by retinal ganglion cells that set the circadian clock. Science, 295(5557), 1070-1073.

28. Bibri, S. E., \& Krogstie, J. (2016). On the Social Shaping Dimensions of Smart Sustainable Cities: A Study in Science, Technology, and Society. Sustainable Cities and Society, In Press.

29. Bluyssen, P. M. (2010). Towards new methods and ways to create healthy and comfortable buildings. Building and Environment, 45, 808-818.

30. Bluyssen, P. M., Aries, M., \& van Dommelen, P. (2011). Comfort of workers in office buildings: The European HOPE project. Building and Environment, 46(1), 280-288.

31. Boechat, J. L., Rios, J. L., Ramos, M. C., Luiz, R. R., Neto, F. A., \& e Silva, J. L. (2011). Sick Building Syndrome (SBS) Among Office Workers and Exposure to Indoor Fungal Allergens in Rio de Janeiro, Brazil. Journal of Allergy and Clinical Immunology, 127(2), AB178.

32. Bonetta, S., Bonetta, S., Mosso, S., Sampò, S., \& Carraro, E. (2010). Assessment of microbiological indoor air quality in an Italian office building equipped with an HVAC system. Environmental monitoring and assessment, 161(1-4), 473483.

33. Boubekri, M. (2008). Daylighting, architecture and health. Routledge.

34. Browning, B. (2012). The Economics of Biophilia: Why designing with nature in mind makes sense. Available: http://202020vision.com.au/media/1024/the-economics-of-biophilia_terrapin-bright-green-2012e.pdf. Last accessed 14 October 2017.

35. Bullinger, M., Morfeld, M., Von Mackensen, S., \& Brasche, S. (1999). The Sick-Building-Syndrome-Do women suffer more?: Das Sick-Building-Syndrom-Leiden Frauen mehr? Zentralblatt für Hygiene und Umweltmedizin, 202(2-4), 235241.

36. Cajochen, C. (2007). Alerting effects of light. Sleep Med Rev, 11, 453-464.

37. Capeluto, G., \& Ochoa, C. E. (2017). What Is a Real Intelligent Envelope?. In Intelligent Envelopes for HighPerformance Buildings. Springer International Publishing, DOI: 10.1007/978-3-319-39255-4_1, 1-20.

38. Chang, C. J., Yang, H. H., Wang, Y. F., \& Li, M. S. (2015). Prevalence of Sick Building Syndrome-Related Symptoms among Hospital Workers in Confined and Open Working Spaces. Aerosol and Air Quality Research, 15(6S), $2378-2384$.

39. Cheong, K. W. D., Yu, W. J., Tham, K. W., Sekhar, S. C., \& Kosonen, R. (2006). A study of perceived air quality and sick building syndrome in a field environment chamber served by displacement ventilation system in the tropics. Building and environment, 41(11), 1530-1539.

40. Chen, J., Rahman, N. M., \& Atiya, I. A. (2010). Radon exhalation from building materials for decorative use. Journal of environmental radioactivity, 101(4), 317-322.

41. Choi, H., Schmidbauer, N., \& Bornehag, C. G. (2017). Volatile organic compounds of possible microbial origin and their risks on childhood asthma and allergies within damp homes. Environment International, 98, 143-151.

42. Chua, S. J. L., Ali, A. S., \& Lim, M. E. L. (2016). Physical Environment Comfort Impacts on Office Employee's Performance. In MATEC Web of Conferences. EDP Sciences, 66, 00124.

43. Clements-Croome, D., (2018). Chapters 1 and 2 in Creating the Productive Workplace: Places to Work Creatively.Ed.Clements-Croome, Routledge.

44. Clements-Croome, D. J. (2008). Work performance, productivity and indoor air. Scandinavian Journal of Work Environment \& Health, (Supplement), 69-78.

45. Cooper, I. (2009) Sustainable urban development and the professions in the UK: Moving from a 'zero sum game' towards more deliberative practice? pages 99-126 in Cooper, I. and Symes, M. (eds.). Sustainable Urban Development Volume 4: Changing Professional Practice. London: Routledge.

46. Cramer, J. S., \& Browning, W. D. (2008). Transforming Building Practices Through Biophilic Design (pp335-346). In S. F. Kellert, J. H. Heerwagen, \& M. L. Mador (Eds.), Biophilic Design. Hoboken, NJ: Wiley.

47. Christensen, D. M., Iddins, C. J., \& Sugarman, S. L. (2014). Ionizing radiation injuries and illnesses. Emergency Medicine Clinics, 32(1), 245-265.

48. Crawford, J. O., \& Bolas, S. M. (1996). Sick building syndrome, work factors and occupational stress. Scandinavian journal of work, environment \& health, 243-250.

49. Crook, B., \& Burton, N. C. (2010). Indoor moulds, sick building syndrome and building related illness. Fungal Biology Reviews, 24(3), 106-113.

50. Croymans, T., Leonardi, F., Trevisi, R., Nuccetelli, C., Schreurs, S., \& Schroeyers, W. (2018). Gamma exposure from building materials-A dose model with expanded gamma lines from naturally occurring radionuclides applicable in nonstandard rooms. Construction and Building Materials, 159, 768-778. 
51. Davis, R. E., McGregor, G. R., \& Enfield, K. B. (2016). Humidity: a review and primer on atmospheric moisture and human health. Environmental research, 144, 106-116.

52. De Been, I., \& Beijer, M. (2014). The influence of office type on satisfaction and perceived productivity support. Journal of Facilities Management, 12(2), 142-157.

53. de Kluizenaar, Y., Roda, C., Dijkstra, N. E., Fossati, S., Mandin, C., Mihucz, V. G., ... \& Bartzis, J. (2016). Office characteristics and dry eye complaints in European workers-The OFFICAIR study. Building and Environment, 102, 5463.

54. de Magalhães Rios, J. L., Boechat, J. L., Gioda, A., dos Santos, C. Y., de Aquino Neto, F. R., \& e Silva, J. R. L. (2009). Symptoms prevalence among office workers of a sealed versus a non-sealed building: associations to indoor air quality. Environment International, 35(8), 1136-1141.

55. Dimitroulopoulou, C. (2012). Ventilation in European dwellings: A review. Building and Environment, 47, 109-125.

56. Engvall, K., Hult, M., Corner, R., Lampa, E., Norbäck, D., \& Emenius, G. (2010). A new multiple regression model to identify multi-family houses with a high prevalence of sick building symptoms "SBS", within the healthy sustainable house study in Stockholm (3H). International archives of occupational and environmental health, 83(1), 85-94.

57. EPA. (2004). United States Environmental Protection Agency (EPA). EPA Science Inventory. 21th century mold analysis in food. Available on: https://cfpub.epa.gov/si/si_public_record_report.cfm?dirEntryId=75868. Accessed: 26/03/2017.

58. EPA. (1991). Indoor Air Facts No. 4 (revised) Sick Building Syndrome. Environmental Protection. Avalible on: https://www.epa.gov/sites/production/files/2014-08/documents/sick_building_factsheet.pdf. Accessed: 2.10.2018.

59. Etemadinezhad, S., Esmaili Naftchali, N., Alizade Larimi, A., \& Yazdani Charati, J. (2017). Prevalence of Sick Building Syndrome in Bank Employees and its Relationship with Job Satisfaction and Some Environmental Factors. Journal of Mazandaran University of Medical Sciences, 27(152), 153-164.

60. European Council, laying down basic safety standards for protection against the dangers arising from exposure to ionising radiation, and repealing directives 89/618/Euratom, 90/641/Euratom, 96/29/Euratom, 97/43/Euratom and 2003/122/Euratom, Off. J. Eur. Union (2014) 1-73.

61. Fang, L., Wyon, D. P., Clausen, G., \& Fanger, P. O. (2004). Impact of indoor air temperature and humidity in an office on perceived air quality, SBS symptoms and performance. Indoor Air, 14(7), 74-81.

62. Fisk, W. J. (2011). Potential nationwide improvements in productivity and health from better indoor environments. Lawrence Berkeley National Laboratory, Available on: http://escholarship.org/uc/item/2cr4m7x5\#page-2. Visited: 26/11/2016.

63. Fisk, W. J., Black, D., \& Brunner, G. (2011). Benefits and costs of improved IEQ in US offices. Indoor Air, 21(5), $357-$ 367.

64. Fisk, W. J., Black, D., \& Brunner, G. (2012). Changing ventilation rates in US offices: Implications for health, work performance, energy, and associated economics. Building and Environment, 47, 368-372.

65. Fife, B. (2017). Health Hazards of Electromagnetic Radiation. Piccadilly Books, Ltd.

66. Foustalieraki, M., Assimakopoulos, M. N., Santamouris, M., \& Pangalou, H. (2017). Energy performance of a medium scale green roof system installed on a commercial building using numerical and experimental data recorded during the cold period of the year. Energy and Buildings, 135, 33-38.

67. Gavhed, D., \& Toomingas, A. (2007). Observed physical working conditions in a sample of call centres in Sweden and their relations to directives, recommendations and operators' comfort and symptoms. International Journal of Industrial Ergonomics, 37(9), 790-800.

68. Gehring, U., Strikwold, M., Schram-Bijkerk, D., Weinmayr, G., Genuneit, J., Nagel, G., ... \& Di Domenicantonio, R. (2008). Asthma and allergic symptoms in relation to house dust endotoxin: Phase Two of the International Study on Asthma and Allergies in Childhood (ISAAC II). Clinical \& Experimental Allergy, 38(12), 1911-1920.

69. Gens, A., Hurley, J. F., Tuomisto, J. T., \& Friedrich, R. (2014). Health impacts due to personal exposure to fine particles caused by insulation of residential buildings in Europe. Atmospheric Environment, 84, 213-221.

70. Ghaffarianhoseini, A., Ghaffarianhoseini, A., Tookey, J., Omrany, H., Fleury, A., Naismith, N., \& Ghaffarianhoseini, M. (2016). The Essence of Smart Homes: Application of Intelligent Technologies. Creative Technologies for Multidisciplinary Applications, 334.

71. Ghashghaei, A., Hussein, H., Ghaffarianhosein, A., \& Ghaffarianhoseini, A. (2017). An Experimental Comparison of the Effectiveness of Cool Colors as Environmental Stimulus on the Elderlies in High-rise Condominiums of Kuala Lumpur. Journal of Design and Built Environment, 17(1): 36-62.

72. Glen, F. C., Smith, N. D., Jones, L., \& Crabb, D. P. (2016). 'I didn't see that coming': simulated visual fields and driving hazard perception test performance. Clinical and Experimental Optometry, 99(5), 469-475.

73. Gomzi, M., \& Bobić, J. (2009). Sick building syndrome. Do we live and work in unhealthy environment? Periodicum biologorum, 111(1), 79-84.

74. Gomzi, M., Bobic, J., Radosevic-Vidacek, B., Macan, J., Varnai, V. M., Milkovic-Kraus, S., \& Kanceljak-Macan, B. (2007). Sick building syndrome: psychological, somatic, and environmental determinants. Archives of environmental \& occupational health, 62(3), 147-155.

75. Goldman , L . ( 1996 ). How sick is your building . Utilities L Review . 12 (3) , $14-15$.

76. Graudenz, G. S. (2011). Building Related Illnesses. In Sick Building Syndrome. Springer Berlin Heidelberg, 341-352.

77. Greer, C. (2007). Something in the air: A critical review of literature on the topic of sick building syndrome. World Saf $J, 16(1), 23-26$ 
78. Gül, H. (2011). Sick Building Syndrome from the Perspective of Occupational and Public Health. In Sick Building Syndrome. Springer Berlin Heidelberg, 89-104.

79. Gupta, S., Khare, M., \& Goyal, R. (2007). Sick building syndrome-A case study in a multistory centrally air-conditioned building in the Delhi City. Building and Environment, 42(8), 2797-2809.

80. Genuis, S. J. (2008). Fielding a current idea: exploring the public health impact of electromagnetic radiation. Public Health, 122(2), 113-124.

81. Heidari, L., Younger, M., Chandler, G., Gooch, J., \& Schramm, P. (2017). Integrating Health Into Buildings of the Future. Journal of Solar Energy Engineering, 139(1), 010802.

82. Hill, S., \& Lorenz, D. (2011). Rethinking professionalism: guardianship of land and resources. Building Research \& Information, 39(3), 314-319.

83. Ho, D. C., Leung, H. F., Wong, S. K., Cheung, A. K. C., Lau, S. S. Y., Wong, W. S., ... \& Chau, K. W. (2004). Assessing the health and hygiene performance of apartment buildings. Facilities, 22(3/4), 58-69.

84. Human spaces report (2015). The global impact of biophilic design in the workplace.

85. Humphreys, M., Nicol, F., Roaf, S., \& Sykes, O. (2015). Standards for Thermal Comfort: Indoor Air Temperature Standards for the 21st Century. Routledge.

86. Hwang, T., \& Kim, J. T. (2010). Effects of indoor lighting on occupants' visual comfort and eye health in a green building. Indoor and Built Environment, 1420326X10392017.

87. Ikei, H., Komatsu, M., Song, C. R., Himoro, E., \&Miyazaki, Y. (2014). The physiological and psychological relaxing effects of viewing rose flowers in office workers. Journal of Physiological Anthropology, 33(6), 1-5.

88. Imai, N., \& Imai, Y. (2011). Psychosocial Factors that Aggravate the Symptoms of Sick Building Syndrome and a Cure for Them. In Sick Building Syndrome. Springer Berlin Heidelberg, 105-111.

89. Iossifova, Y. Y., Reponen, T., Bernstein, D. I., Levin, L., Kalra, H., Campo, P., ... \& LeMasters, G. (2007). House dust (1-3)- $\beta$-d-glucan and wheezing in infants. Allergy, 62(5), 504-513.

90. Ismaila, S. O., \& Odusote, A. (2014). Noise exposure as a factor in the increase of blood pressure of workers in a sack manufacturing industry. Beni-Suef University Journal of Basic and Applied Sciences, 3(2), 116-121.

91. Jaber, S., \& Ezzat, A. W. (2017). Investigation of energy recovery with exhaust air evaporative cooling in ventilation system. Energy and Buildings, 139, 439-448.

92. Jafari, M. J., Khajevandi, A. A., Najarkola, S. A. M., Yekaninejad, M. S., Pourhoseingholi, M. A., Omidi, L., \& Kalantary, S. (2015). Association of sick building syndrome with indoor air parameters. Tanaffos, 14(1), 55.

93. Kaplan, S. (1995). The restorative benefits of nature: Toward an integrative framework. Journal of Environmental Psychology, 15, 169-182.

94. Jansz, J. (2011a). Introduction to sick building syndrome. In Sick Building Syndrome. Springer Berlin Heidelberg., 124.

95. Jansz, J. (2011b). Theories and knowledge about sick building syndrome. In Sick Building Syndrome. Springer Berlin Heidelberg, 25-58.

96. Johansson, P., Svensson, T., \& Ekstrand-Tobin, A. (2013). Validation of critical moisture conditions for mould growth on building materials. Building and Environment, 62, 201-209.

97. Karakolis, T., \& Callaghan, J. P. (2014). The impact of sit-stand office workstations on worker discomfort and productivity: a review. Applied ergonomics, 45(3), 799-806.

98. Kamaruzzaman, S., \& Sabrani, NA. (2011). The effect of indoor air quality (IAQ) towards occupants' psychological performance in office buildings. Jurnal Rekabentuk dan Binaan, 4, 49-61.

99. Kaplan, R. (1992). The psychological benefits of nearby nature. In Role of horticulture in human well-being and social development: A national symposium. Arlington, Va.: Timber Press, 125-133.

100. Kellert, S. R., \& Wilson, E. O. (1993). The Biophilia hypothesis. Washington, DC: Island Press.

101. Kellert, R. (2012). Birthright: People and Nature in the Modern World. Yale University Press.

102. Khaiwal, R., Singh, T., Tripathy, J. P., Mor, S., Munjal, S., Patro, B., \& Panda, N. (2016). Assessment of noise pollution in and around a sensitive zone in North India and its non-auditory impacts. Science of The Total Environment, 566, 981987.

103. Kim, S. S., Kang, D. H., Choi, D. H., Yeo, M. S., \& Kim, K. W. (2008). Comparison of strategies to improve indoor air quality at the pre-occupancy stage in new apartment buildings. Building and Environment, 43(3), 320-328.

104. Kowalska, J., Szewczyńska, M., \& Pośniak, M. (2015). Measurements of chlorinated volatile organic compounds emitted from office printers and photocopiers. Environmental Science and Pollution Research, 22(7), 5241-5252.

105. Largo-Wight, E., Chen, W. W., Dodd, V., \& Weiler, R. (2011). Healthy workplaces: The effects of nature contact at work on employee stress and health. Public Health Reports, 126(1_suppl), 124-130.

106. Lan, L., Wargocki, P., Wyon, D. P., \& Lian, Z. (2011). Effects of thermal discomfort in an office on perceived air quality, SBS symptoms, physiological responses, and human performance. Indoor Air, 21(5), 376-390.

107. Leder, S., Newsham, G. R., Veitch, J. A., Mancini, S., \& Charles, K. E. (2016). Effects of office environment on employee satisfaction: A new analysis. Building Research \& Information, 44(1), 34-50.

108. Levin, H. (1995). Building ecology: an architect's perspective on healthy buildings. Proceedings of the Fourth International Conference Healthy Buildings, Avaliable on: http://www.buildingecology.net/index_files/publications/DesignandConstructionofHealthyandSustainableBuildings.pdf. 
109. Li, X., Song, Z., Wang, T., Zheng, Y., \& Ning, X. (2016). Health impacts of construction noise on workers: A quantitative assessment model based on exposure measurement. Journal of Cleaner Production, 135, 721-731.

110. Li, X., Su, S., Zhang, Z., Kong, X. (2017). An integrated environmental and health performance quantification model for pre-occupancy phase of buildings in China Environmental Impact Assessment Review, 63, 1-11.

111. Lilis, G., Conus, G., Asadi, N., \& Kayal, M. (2016). Towards the next generation of intelligent building: An assessment study of current automation and future IoT based systems with a proposal for transitional design. Sustainable Cities and Society, In Press.

112. Lim, F. L., Hashim, Z., Said, S. M., Than, L. T. L., Hashim, J. H., \& Norbäck, D. (2015). Sick building syndrome (SBS) among office workers in a Malaysian university-Associations with atopy, fractional exhaled nitric oxide (FeNO) and the office environment. Science of The Total Environment, 536, 353-361.

113. Loftness, V., Hakkinen, B., Adan, O., \& Nevalainen, A. (2007). Elements that contribute to healthy building design. Environmental Health Perspectives, 115(6), 965.

114. Loupa, G., Fotopoulou, S., \& Tsagarakis, K. P. (2015). A tool for analysing the interdependence of indoor environmental quality and reported symptoms of the hospitals' personnel. Journal of Risk Research, DOI:10.1080/13669877.2015.1119182.

115. Lu, C., Deng, Q., Li, Y., Sundell, J., \& Norbäck, D. (2016). Outdoor air pollution, meteorological conditions and indoor factors in dwellings in relation to sick building syndrome (SBS) among adults in China. Science of The Total Environment, 560, 186-196.

116. Lu, X., Yang, G., \& Ren, C. (2012). Natural radioactivity and radiological hazards of building materials in Xianyang, China. Radiation Physics and Chemistry, 81(7), 780-784.

117. Ludlow, A. M. (1976). The functions of windows in buildings. Lighting Research \& Technology, 8(2), 57-68.

118. Lee, S. C., Lam, S., \& Fai, H. K. (2001). Characterization of VOCs, ozone, and PM 10 emissions from office equipment in an environmental chamber. Building and Environment, 36(7), 837-842.

119. Lukcso, D., Guidotti, T. L., Franklin, D. E., \& Burt, A. (2016). Indoor environmental and air quality characteristics, building-related health symptoms, and worker productivity in a federal government building complex. Archives of environmental \& occupational health, 71(2), 85-101.

120. MacNaughton, P., Satish, U., Laurent, J. G. C., Flanigan, S., Vallarino, J., Coull, B., ... \& Allen, J. G. (2017). The impact of working in a green certified building on cognitive function and health. Building and Environment, 114, 178-186.

121. MacNaughton, P., Spengler, J., Vallarino, J., Santanam, S., Satish, U., \& Allen, J. (2016). Environmental perceptions and health before and after relocation to a green building. Building and Environment, 104, 138-144.

122. Magnavita, N. (2015). Work-related symptoms in indoor environments: a puzzling problem for the occupational physician. International archives of occupational and environmental health, 88(2), 185-196.

123. Mak, C. M., \& Lui, Y. P. (2011). The effect of sound on office productivity. Building Services Engineering Research and Technology, 0143624411412253.

124. Mangkuto, R. A., Rohmah, M., \& Asri, A. D. (2016). Design optimisation for window size, orientation, and wall reflectance with regard to various daylight metrics and lighting energy demand: A case study of buildings in the tropics. Applied Energy, 164, 211-219.

125. Maoz-Segal, R., Agmon-Levin, N., Israeli, E., \& Shoenfeld, Y. (2015). The sick building syndrome as a part of'ASIA'(autoimmune/auto-inflammatory syndrome induced by adjuvants). Harefuah, 154(2), 129-132.

126. Martos, A., Pacheco-Torres, R., Ordóñez, J., \& Jadraque-Gago, E. (2016). Towards successful environmental performance of sustainable cities: Intervening sectors. A review. Renewable and Sustainable Energy Reviews, 57, 479495.

127. Mateus, N. M., Simões, G. N., Lúcio, C., \& da Graça, G. C. (2016). Comparison of measured and simulated performance of natural displacement ventilation systems for classrooms. Energy and Buildings, 133, 185-196.

128. Matsunaga, K., Park, B. J., Kobayashi, H., \& Miyazaki, Y. (2011). Physiologically relaxing effect of a hospital rooftop forest on older women requiring care. Journal of the American Geriatrics Society, 59, 2162-2163.

129. Mavi, B., \& Akkurt, I. (2010). Natural radioactivity and radiation hazards in some building materials used in Isparta, Turkey. Radiation Physics and Chemistry, 79(9), 933-937.

130. Miller, N., Pogue, D., Gough, Q., \& Davis, S. (2009). Green buildings and productivity. Journal of Sustainable Real Estate, 1(1), 65-89.

131. Mirrahimi, S., Mohamed, M. F., Haw, L. C., Ibrahim, N. L. N., Yusoff, W. F. M., \& Aflaki, A. (2016). The effect of building envelope on the thermal comfort and energy saving for high-rise buildings in hot-humid climate. Renewable and Sustainable Energy Reviews, 53, 1508-1519.

132. Moher, D., Liberati, A., Tetzlaff, J., Altman, D.G. (2009). The PRISMA Group. Preferred reporting items forsystematic reviews and meta-analyses: The PRISMA statement. PLoS Med.2009, 6, 1-6.

133. Mohtashami, N., Mahdavinejad, M., \& Bemanian, M. (2016). Contribution of City Prosperity to Decisions on Healthy Building Design: A case study of Tehran. Frontiers of Architectural Research, 5(3), 319-331.

134. Molina, C., Anthony, C., Pickering, C., Valbjorn, O., and Bortoli, M. (1989). Sick Building Syndrome; A practical guide. Commission of the European communities, Luxembourg. Accessed via: http://www.buildingecology.com/publications/ECA_Report4.pdf, Last accessed: 18 October 2017.

135. Murphy, M. (2006). Sick building syndrome and the problem of uncertainty: Environmental politics, technoscience, and women workers. Duke University Press. 
136. Newsham, G., Brand, J., Donnelly, C., Veitch, J., Aries, M., \& Charles, K. (2009). Linking indoor environment conditions to job satisfaction: a field study. Building Research \& Information, 37(2), 129-147.

137. Norbäck, D. (2009). An update on sick building syndrome. Current opinion in allergy and clinical immunology, 9(1), 55-59.

138. Norbäck, D., \& Nordström, K. (2008). Sick building syndrome in relation to air exchange rate, CO2, room temperature and relative air humidity in university computer classrooms: an experimental study. International archives of occupational and environmental health, 82(1), 21-30.

139. Norbäck, D., Hashim, J. H., Cai, G. H., Hashim, Z., Ali, F., Bloom, E., \& Larsson, L. (2016). Rhinitis, Ocular, Throat and Dermal Symptoms, Headache and Tiredness among Students in Schools from Johor Bahru, Malaysia: Associations with Fungal DNA and Mycotoxins in Classroom Dust. PloS one, 11(2), e0147996.

140. Norbäck, D., Hashim, J. H., Hashim, Z., Cai, G. H., Sooria, V., Ismail, S. A., \& Wieslander, G. (2017). Respiratory symptoms and fractional exhaled nitric oxide (FeNO) among students in Penang, Malaysia in relation to signs of dampness at school and fungal DNA in school dust. Science of The Total Environment, 577, 148-154.

141. Norbäck, D., Hashim, J. H., Markowicz, P., Cai, G. H., Hashim, Z., Ali, F., \& Larsson, L. (2016). Endotoxin, ergosterol, muramic acid and fungal DNA in dust from schools in Johor Bahru, Malaysia-Associations with rhinitis and sick building syndrome (SBS) in junior high school students. Science of The Total Environment, 545, 95-103.

142. Norhidayah, A., Chia-Kuang, L., Azhar, M. K., \& Nurulwahida, S. (2013). Indoor air quality and sick building syndrome in three selected buildings. Procedia Engineering, 53, 93-98.

143. Omrany, H., Ghaffarianhoseini, A., Ghaffarianhoseini, A., Raahemifar, K., \& Tookey, J. (2016). Application of passive wall systems for improving the energy effciency in buildings: A comprehensive review. Renewable and Sustainable Energy Reviews, 62, 1252-1269.

144. Omrany, H., \& Marsono, A. K. (2016). Optimization of building energy performance through passive design strategies. British Journal of Applied Science \& Technology, 13(6), 1-16.

145. Park, S. H., \& Mattson, R. H. (2008). Effects of flowering and foliage plants in hospital rooms on patients recovering from abdominal surgery. Horttechnology, 18, 563-568.

146. Park, H. S., Ji, C., \& Hong, T. (2016). Methodology for assessing human health impacts due to pollutants emitted from building materials. Building and Environment, 95, 133-144.

147. Paul, W. L., \& Taylor, P. A. (2008). A comparison of occupant comfort and satisfaction between a green building and a conventional building. Building and Environment, 43(11), 1858-1870.

148. Pegas, P. N., Alves, C. A., Evtyugina, M. G., Nunes, T., Cerqueira, M., Franchi, M., ... \& Freitas, M. C. (2011). Indoor air quality in elementary schools of Lisbon in spring. Environmental Geochemistry and Health, 33(5), 455-468.

149. Pérez, G., Coma, J., Sol, S., \& Cabeza, L. F. (2017). Green facade for energy savings in buildings: The influence of leaf area index and facade orientation on the shadow effect. Applied Energy, 187, 424-437.

150. Perrin Jegen, N., \& Chevret, P. (2016). Effect of noise on comfort in open-plan offices: application of an assessment questionnaire. Ergonomic, 1-12.

151. Petry, T., Vitale, D., Joachim, F. J., Smith, B., Cruse, L., Mascarenhas, R., ... \& Singal, M. (2014). Human health risk evaluation of selected VOC, SVOC and particulate emissions from scented candles. Regulatory Toxicology and Pharmacology, 69(1), 55-70.

152. Polizzi, V., Adams, A., Picco, A. M., Adriaens, E., Lenoir, J., Van Peteghem, C., ... \& De Kimpe, N. (2011). Influence of environmental conditions on production of volatiles by Trichoderma atroviride in relation with the sick building syndrome. Building and Environment, 46(4), 945-954.

153. Raanaas, R. K., Evensen, K. H., Rich, D., Sjøstrøm, G., \& Patil, G. (2011). Benefits of indoor plants on attention capacity in an office setting. Journal of Environmental Psychology, 31(1), 99-105.

154. Ravisankar, R., Vanasundari, K., Chandrasekaran, A., Rajalakshmi, A., Suganya, M., Vijayagopal, P., \& Meenakshisundaram, V. (2012). Measurement of natural radioactivity in building materials of Namakkal, Tamil Nadu, India using gamma-ray spectrometry. Applied Radiation and Isotopes, 70(4), 699-704.

155. Realyvásquez, A., Maldonado-Macías, A. A., García-Alcaraz, J., Cortés-Robles, G., \& Blanco-Fernández, J. (2016). Structural Model for the Effects of Environmental Elements on the Psychological Characteristics and Performance of the Employees of Manufacturing Systems. International journal of environmental research and public health, 13(1), 104.

156. Rees, W. E. (1999). The built environment and the ecosphere: a global perspective. Building Research \& Information, 27(4-5), 206-220.

157. Roberts, P. (2009). Sustainable communities, policy, practice and professional development: A model for Europe. In I Cooper and M Symes (Eds.): Sustainable urban development, Vol. 4:Changing professional practice (pp. 127-144). Abingdon: Routledge.

158. Runeson-Broberg, R., \& Norbäck, D. (2013). Sick building syndrome (SBS) and sick house syndrome (SHS) in relation to psychosocial stress at work in the Swedish workforce. International archives of occupational and environmental health, 86(8), 915-922.

159. Rostron, J. (2008). Sick building syndrome: A review of causes, consequences and remedies. Journal of Retail \& Leisure Property, 7(4), 291-303.

160. Rydstedt, L. W. (2016). Psychosocial job strain as a mediator between physical working conditions and symptoms associated with sick building syndrome. Human Affairs, 26(4), 440-449. 
161. Ryan, C. O., Browning, W. O., Clancy, J. O., Andrews, S. L., \& Kallianpurkar, N. B. (2014). Biophilic design patterns: Emerging nature-based parameters for health and well-being in the built environment. Archnet International Journal of Architectural Research, 8(2), 62-76.

162. Sahlberg, B., Gunnbjörnsdottir, M., Soon, A., Jogi, R., Gislason, T., Wieslander, G., ... \& Norback, D. (2013). Airborne molds and bacteria, microbial volatile organic compounds (MVOC), plasticizers and formaldehyde in dwellings in three North European cities in relation to sick building syndrome (SBS). Science of The Total Environment, 444, 433-440.

163. Sahlberg, B., Mi, Y. H., \& Norbäck, D. (2009). Indoor environment in dwellings, asthma, allergies, and sick building syndrome in the Swedish population: a longitudinal cohort study from 1989 to 1997. International archives of occupational and environmental health, 82(10), 1211-1218.

164. Saijo, Y., Nakagi, Y., Ito, T., Sugioka, Y., Endo, H., \& Yoshida, T. (2010). Dampness, food habits, and sick building syndrome symptoms in elementary school pupils. Environmental health and preventive medicine, 15(5), $276-284$.

165. Satish, U., Mendell, M. J., Shekhar, K., Hotchi, T., Sullivan, D., Streufert, S., \& Fisk, W. J. (2012). Is $\mathrm{CO}_{2}$ an indoor pollutant? Direct effects of low-to-moderate $\mathrm{CO} 2$ concentrations on human decision-making performance. Environmental Health Perspectives, 120(12), 1671.

166. Seidman, M. D., \& Standring, R. T. (2010). Noise and quality of life. International journal of environmental research and public health, 7(10), 3730-3738.

167. Seppanen, O., Fisk, W. J., \& Lei, Q. H. (2006). Effect of temperature on task performance in office environment. Lawrence Berkeley National Laboratory.

168. Shan, X., Zhou, J., Chang, V. W. C., \& Yang, E. H. (2016). Comparing mixing and displacement ventilation in tutorial rooms: Students' thermal comfort, sick building syndromes, and short-term performance. Building and Environment, 102, 128-137.

169. Sheikhmohammadi, A., Sardar, M., \& Almasian, M. (2016). A survey of sick building syndrome prevalence among the inhabitants of ekbatan in Tehran. Environmental Engineering \& Management Journal (EEMJ), 15(4), 755-760.

170. Shi, X., Zhu, N., \& Zheng, G. (2013). The combined effect of temperature, relative humidity and work intensity on human strain in hot and humid environments. Building and Environment, 69, 72-80.

171. Singh, A., Syal, M., Grady, S. C., \& Korkmaz, S. (2010). Effects of green buildings on employee health and productivity. American journal of public health, 100(9), 1665-1668.

172. Singh, J. (2005). Toxic moulds and indoor air quality. Indoor and Built Environment, 14(3-4), 229-234.

173. Singh, J., Yu, C. W. F., \& Kim, J. T. (2010). Building pathology, investigation of sick buildings-toxic moulds. Indoor and Built Environment, 19(1), 40-47.

174. Söderlund, J., \& Newman, P. (2017). Improving Mental Health in Prisons Through Biophilic Design. The Prison Journal, 97 (6), 750-772.

175. Sofuoglu, S. C., Aslan, G., Inal, F., \& Sofuoglu, A. (2011). An assessment of indoor air concentrations and health risks of volatile organic compounds in three primary schools. International Journal of Hygiene and Environmental Health, 214(1), 36-46.

176. Steinemann, A., Wargocki, P., \& Rismanchi, B. (2016). Ten questions concerning green buildings and indoor air quality. Building and Environment, In Press.

177. Sun, Y., Zhang, Y., Bao, L., Fan, Z., Wang, D., \& Sundell, J. (2013). Effects of gender and dormitory environment on sick building syndrome symptoms among college students in Tianjin, China. Building and Environment, 68, 134-139.

178. Sundell, J., Levin, H., Nazaroff, W. W., Cain, W. S., Fisk, W. J., Grimsrud, D. T., ... \& Samet, J. M. (2011). Ventilation rates and health: multidisciplinary review of the scientific literature. Indoor Air, 21(3), 191-204.

179. Saad, A. F., Al-Awami, H. H., \& Hussein, N. A. (2014). Radon exhalation from building materials used in Libya. Radiation Physics and Chemistry, 101, 15-19.

180. Schroeyers, W., Sas, Z., Bator, G., Trevisi, R., Nuccetelli, C., Leonardi, F., ... \& Kovacs, T. (2018). The NORM4Building database, a tool for radiological assessment when using by-products in building materials. Construction and Building Materials, 159, 755-767.

181. Takaoka, M., Suzuki, K., \& Norbäck, D. (2016). Sick Building Syndrome Among Junior High School Students in Japan in Relation to the Home and School Environment. Global journal of health science, 8(2), 165-177.

182. Takeda, M., Saijo, Y., Yuasa, M., Kanazawa, A., Araki, A., \& Kishi, R. (2009). Relationship between sick building syndrome and indoor environmental factors in newly built Japanese dwellings. International archives of occupational and environmental health, 82(5), 583-593.

183. Takigawa, T., Saijo, Y., Morimoto, K., Nakayama, K., Shibata, E., Tanaka, M., ... \& Kishi, R. (2012). A longitudinal study of aldehydes and volatile organic compounds associated with subjective symptoms related to sick building syndrome in new dwellings in Japan. Science of The Total Environment, 417, 61-67.

184. Takigawa, T., Wang, B. L., Saijo, Y., Morimoto, K., Nakayama, K., Tanaka, M., ... \& Kishi, R. (2010). Relationship between indoor chemical concentrations and subjective symptoms associated with sick building syndrome in newly built houses in Japan. International archives of occupational and environmental health, 83(2), 225-235.

185. Takigawa, T., Wang, B. L., Sakano, N., Wang, D. H., Ogino, K., \& Kishi, R. (2009). A longitudinal study of environmental risk factors for subjective symptoms associated with sick building syndrome in new dwellings. Science of The Total Environment, 407(19), 5223-5228.

186. Takki, T., Villberg, K., Hongisto, V., Kosonen, R., \& Korpi, A. (2011). A Continuous and Proactive Process to Enhance Well-being Indoors. In Sick Building Syndrome. 353-370, Springer Berlin Heidelberg. 
187. Thatcher, A., \& Milner, K. (2016). Is a green building really better for building occupants? A longitudinal evaluation. Building and Environment, 108, 194-206.

188. Trained, P. (2011). The Bishop Review: The Future of Design in the Built Environment, Project Report. London: CABE.

189. Tsai, D. H., Lin, J. S., \& Chan, C. C. (2012). Office workers' sick building syndrome and indoor carbon dioxide concentrations. Journal of occupational and environmental hygiene, 9(5), 345-351.

190. TSSA. (2010). Sick building syndrome. Accessed: 29/03/2017. Available: http://www.tssa.org.uk/article47.php3?id_article $=1001$. Accessed: 2.10.2018.

191. Tyrväinen, L., Ojala, A., Korpela, K. Lanki, T., Tsunetsugu,Y., \& Kagawa, T. (2014). The influence of urban green environments on stress relief measures: A field experiment. Journal of Environmental Psychology, 38, 1-9.

192. Ulrich, R. S. (1979). Visual landscapes and psychological well-being (National Parks). Landscape Research, 4, 17-23.

193. Ulrich, R. S. (1984). View through a window may influence recovery from surgery. Science, 224, 420-421.

194. Ulrich, R. S., Simons, R. F., Losito, B. D., Fiorito, E., Miles, M. A., \& Zelson, M. (1991). Stress recovery during exposure to natural and urban environments. Journal of Environmental Psychology, 11, 201-230.

195. USDAW, (2006). Union of Shop, Distributive and Allied Workers, The Guardian, Work section, 8 July. http://www.guardian.co.uk/theguardian/2006/jul/08/work

196. Van, D. A., \& Bergs, J. (2001). Study on Plants and Productivity. Leiden, Bloemenbureau Holland.

197. van Maanen, A., Meijer, A. M., van der Heijden, K. B., \& Oort, F. J. (2016). The effects of light therapy on sleep problems: A systematic review and meta-analysis. Sleep medicine reviews, 29, 52-62.

198. Vereecken, E., \& Roels, S. (2012). Review of mould prediction models and their influence on mould risk evaluation. Building and Environment, 51, 296-310.

199. Vesper, S. J., \& Vesper, M. J. (2004). Possible role of fungal hemolysins in sick building syndrome. Advances in applied microbiology, 55, 191-213.

200. Vimalanathan, K., \& Babu, T. R. (2014). The effect of indoor office environment on the work performance, health and well-being of office workers. Journal of Environmental Health Science and Engineering, 12(1), 113.

201. Vural, S. M., \& Balanl1, A. (2011). Sick building syndrome from an architectural perspective. In Sick Building Syndrome(pp. 371-391). Springer Berlin Heidelberg.

202. Wang, J., Engvall, K., Smedje, G., \& Norbäck, D. (2017). Exacerbation of asthma among adults in relation to the home environment in multi-family buildings in Sweden. The International Journal of Tuberculosis and Lung Disease, 21(2), 223-229.

203. Wang, J., Li, B., Yang, Q., Yu, W., Wang, H., Norback, D., \& Sundell, J. (2013). Odors and sensations of humidity and dryness in relation to sick building syndrome and home environment in Chongqing, China. PloS one, 8(8), e72385.

204. Wang, S. S., Chou, C. F., Chung, F. F., Hsiao, H. F., Huang, C. T., \& Wan, G. H. (2015). Prevalences of Sick Building Syndrome Symptoms in Respiratory Therapists and Hospital Office Workers in a Medical Center. Journal of Respiratory Therapy, 14(2), 1-14.

205. Wargocki, P., Wyon, D. P., Sundell, J., Clausen, G., \& Fanger, P. (2000). The effects of outdoor air supply rate in an office on perceived air quality, sick building syndrome (SBS) symptoms and productivity. Indoor Air, 10(4), $222-236$.

206. Wargorcki, P., Seppänen, O., Andersson, J., Boerstra, A., Clements-Croome, D., Fitzner, K., Hanssen, SO. (2006). REHVA Guidebook: Indoor Climate and Productivity In Offices. REHVA, Brussels.

207. WHO. (1983). World Health Organization. Indoor air pollutants: exposure and health effects. EURO reports and studies, $78,1-42$.

208. WHO. (1986). Indoor Air Quality Research- EURO Reports and Studies WHO Regional Office for Europe, Copenhagen, No. 103.

209. Wilson, E. O. (1984). Biophilia. Cambridge, MA: Harvard University Press.

210. Wong, S. K., Lai, L. W. C., Ho, D. C. W., Chau, K. W., Lam, C. L. K., \& Ng, C. H. F. (2009). Sick building syndrome and perceived indoor environmental quality: A survey of apartment buildings in Hong Kong. Habitat International, 33(4), 463-471.

211. World Green Building Council. (2004). Health, wellbeing and productivity in offices. The next chapter for green building. Accessed via: http://www.jll.com/Research/Health_Wellbeing_Productivity.pdf?1a56c1ad-7be7-4d6d-8f32$74 b b 6 e 72$ fa3f. Last accessed: 10 October 2017.

212. Wyon, D. P. (2004). The effects of indoor air quality on performance and productivity. Indoor air, 14(7), 92-101.

213. Yang, B., Xu, T., \& Shi, L. (2016). Analysis on sustainable urban development levels and trends in China's cities. Journal of Cleaner Production., 141, 868-880.

214. Zamanian, A., \& Hardiman, C. (2005). Electromagnetic radiation and human health: A review of sources and effects. High Frequency Electronics, 4(3), 16-26.

215. Zhang, X., Li, F., Zhang, L., Zhao, Z., \& Norback, D. (2014). A Longitudinal Study of Sick Building Syndrome (SBS) among Pupils in Relation to SO 2, NO 2, O 3 and PM 10 in Schools in China. PloS one, 9(11), e112933.

216. Zhang, X., Sahlberg, B., Wieslander, G., Janson, C., Gislason, T., \& Norback, D. (2012). Dampness and moulds in workplace buildings: Associations with incidence and remission of sick building syndrome (SBS) and biomarkers of inflammation in a 10 year follow-up study. Science of The Total Environment, 430, 75-81.

217. Zhang, X., Zhao, Z., Nordquist, T., \& Norback, D. (2011). The prevalence and incidence of sick building syndrome in Chinese pupils in relation to the school environment: a twoyear followup study. Indoor Air, 21(6), 462-471. 
218. Zhang, X., Zhao, Z., Nordquist, T., Larsson, L., Sebastian, A., \& Norback, D. (2011). A longitudinal study of sick building syndrome among pupils in relation to microbial components in dust in schools in China. Science of The Total Environment, 409(24), 5253-5259.

219. Zheng, G., Zhu, N., Tian, Z., Chen, Y., \& Sun, B. (2012). Application of a trapezoidal fuzzy AHP method for work safety evaluation and early warning rating of hot and humid environments. Safety Science, 50(2), 228-239. 